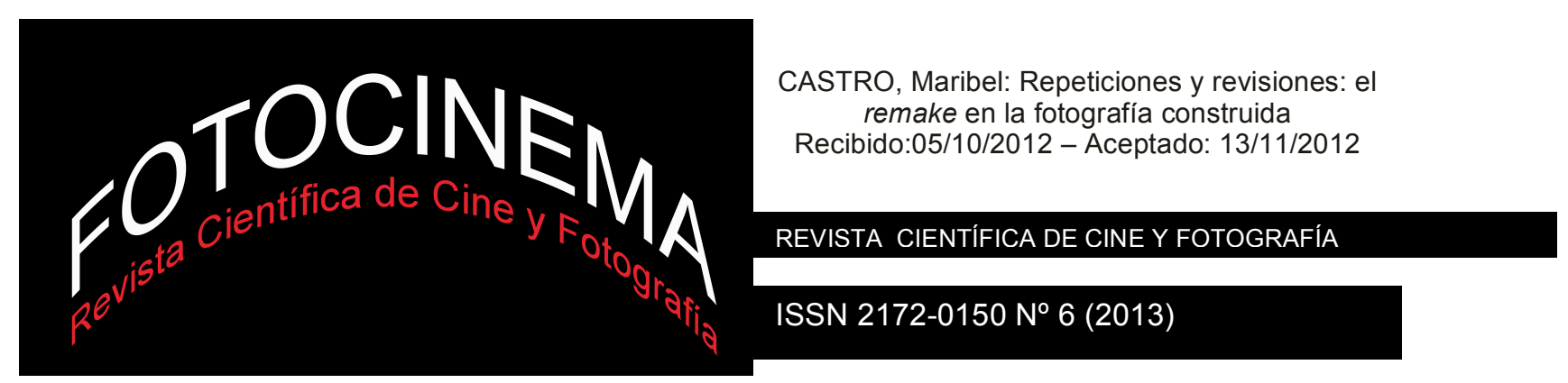

\title{
REPETICIONES Y REVISIONES: EL REMAKE EN LA FOTOGRAFÍA CONSTRUIDA
}

\section{REPETITIONS AND REVISIONS: THE REMAKE IN STAGED PHOTOGRAPHY}

\section{Maribel Castro}

Universidad Complutense de Madrid

\section{Resumen:}

Desde la posmodernidad, la teoría de la fotografía se ha ocupado de la idea de que las fotografías pueden ser entendidas como procesos de significación y codificación cultural. En un contexto artístico interesado por el pastiche, la cita, la deconstrucción y el cuestionamiento de las ideas de autoría y originalidad, el remake se consolida como modo de producción de versiones de iconos pertenecientes al imaginario colectivo, y se convierte en una estrategia representacional recurrente en la fotografía artística actual. Nos reta a reconocer lo que vemos, cuestionar cómo lo vemos, y problematizar cómo las imágenes dan forma a nuestras emociones y comprensión del mundo.

Tras desarrollar el concepto de remake, analizaremos sus implicaciones estéticas, narrativas y representacionales en la fotografía escenificada, mediante el estu-dio de un conjunto de propuestas artísti-cas recientes que hacen uso de un stock de imágenes preexistentes (especialmente procedentes de la Pintura), reelaborándolas con nuevos enfoques que expresan además un compromiso con el presente.

\section{Abstract:}

Since posmodernism, photography theory has dealt with the idea that photographs can be understood as processes of cultural meaning and coding. In an artistic context interested in pastiche, quotation, deconstruction and questioning ideas of authorship and originality, the remake is consolidated as way of producing revisions of icons belonging to the collective imagination, and becomes a recurring representational strategy in current art photography. It challenges us to recognize what we see, to question how we see it, and to problematize how images give shape to our emotions and understanding of the world.

After developing the concept of remake, we will analyze its aesthetic, narrative and representational implications in staged photography, through the study of a set of recent artistic proposals that make use of a stock of preexisting images (specially from Painting), that then are reworked with new approaches that express a strong commitment to the present.

\section{Palabras clave:}

Fotografía escenificada; remake; arte contemporáneo; deconstrucción; originalidad.

\section{Key words:}

Staged photography; remake, contemporary art; deconstruction; originality. 


\section{Introducción: El problema de la originalidad en la posmodernidad}

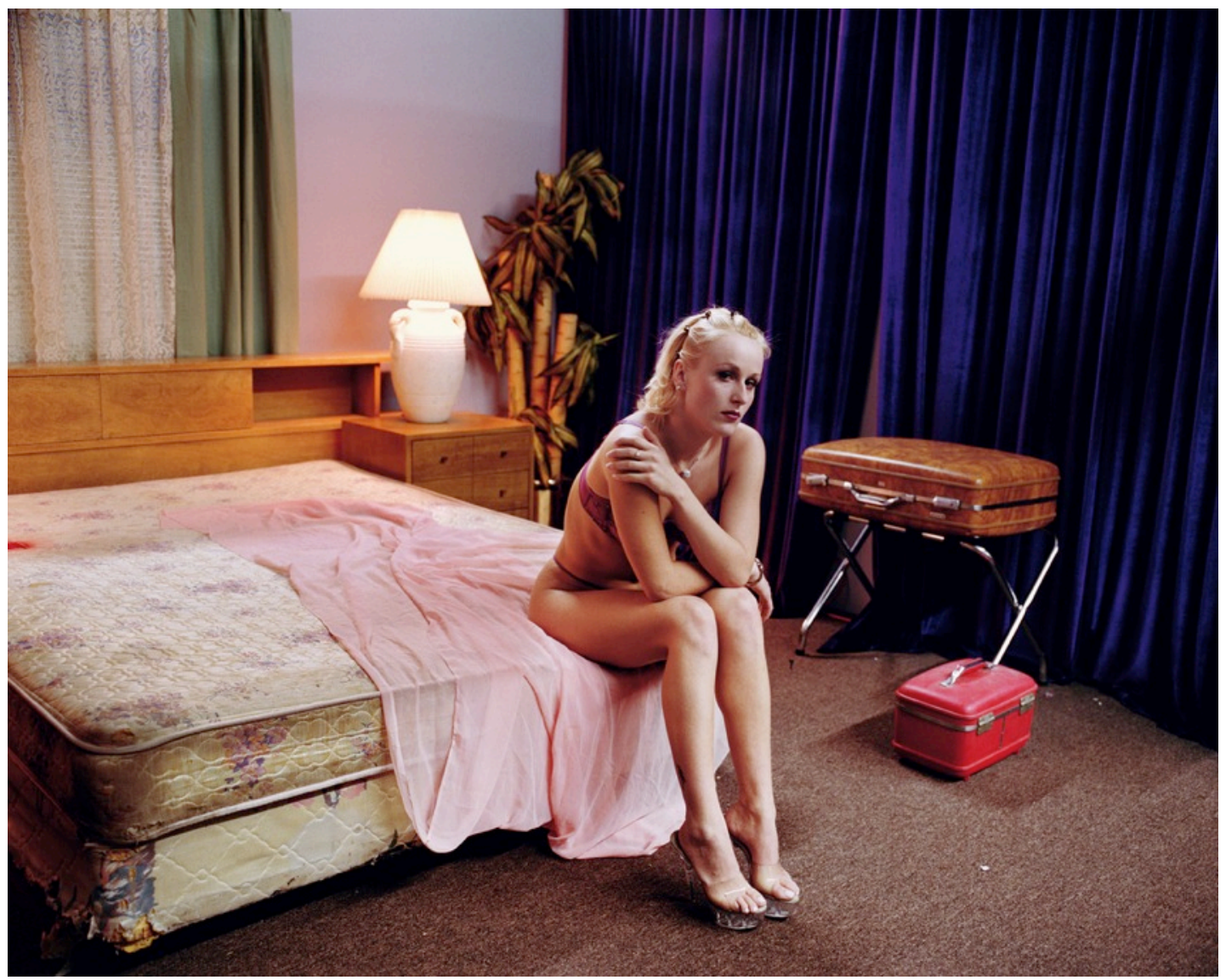

Imagen 1. Larry Sultan: "Sharon Wild", de la serie "The Valley" (2001)

En los últimos años se ha consolidado en la fotografía artística una tendencia a revisar y repetir formas e iconos ya pertenecientes al imaginario colectivo, en especial aquellas que hacen referencia a la historia de la Pintura. Para comprender esta vuelta a los clásicos y a elementos preexistentes vamos a realizar una contextualización en la que enmarcar esta investigación.

En la posmodernidad se destruyen mitos modernos como el del individuo autónomo y el "mito del autor". Barthes (1987: 65-71) argumenta que las ideas no son propias de la persona que produce la obra, sino que pertenecen a la cultura histórica en general. Para dar existencia al lector/espectador como un agente reconstructor, la voz del autor debe desaparecer. Por otro lado, también se destruye el "mito de la originalidad”, como después desarrollaremos.

La producción cultural posmoderna se caracteriza, entre otras cosas, por mezclar medios heterogéneos, así como también por echar mano de materiales o planteamientos alternativos, apartándose del pensamiento moderno de la 
“especificidad del medio". Un signo distintivo de la práctica artística posmoderna es la crítica al canon del arte moderno de Clement Greenberg y Michael Fried, que defendía la autonomía de las disciplinas artísticas según los límites de su propia especificidad, legitimando de un modo formalista un arte despolitizado.

En la obra de arte ya no es tan importante la intención del autor para la construcción del significado, sino la cuestión hermenéutica de cómo esa obra o ese significado funcionan. Este rechazo a la intencionalidad del sujeto está presente a la teoría deconstruccionista de Jacques Derrida (1975, 1989). La reflexión filosófica y cultural es un acontecimiento y una intervención que opera marginalmente (a veces como comentario), sin las pretensiones y estructuras universalistas anteriores.

En el mundo del arte el término posmodernidad supone (entre otras cosas) un corte, una incisión en los supuestos básicos acerca del papel del arte en la cultura y acerca del papel del artista en relación a su arte. Esta función incisiva es conocida como desconstrucción ${ }^{1}$. Bajo este término subyace una teoría relacionada con el modo (basado en el estructuralismo) en que percibimos el mundo, a la vez que lo contradice. Para Derrida, la deconstrucción del lenguaje implica investigar modos en que las palabras (como unidades que se refieren a conceptos particulares) conllevan, por implicación, el borrado de posibilidades referenciales alternativas, operando dentro de una cadena de significación en la que la que cada palabra consiguiente contribuye a orientar la línea de desarrollo de la interpretación. Aquí, el énfasis se hace en el juego de significados, en la laxitud de fijeza.

En la posmodernidad ha tenido una gran influencia el pensamiento semiótico. En el ámbito de lo visual se podría decir que una imagen deriva su fuerza no sólo de aquello que representa, sino también de aquello a lo que se opone. Además, los códigos tecnológicos y estéticos que operan sobre la imagen pueden contribuir a la fluidez de significación. El significado se puede ver aquí, por

\footnotetext{
${ }^{1} \mathrm{La}$ "deconstrucción" es un tipo de pensamiento que analiza, revisa y critica en profundidad las palabras y sus conceptos. El discurso deconstructivista pone de manifiesto la incapacidad de la filosofía para establecer una base estable, sin dejar de reivindicar su carácter analítico.
}

7 
tanto, como un producto del juego dentro de y entre las posibilidades, y no de estructuras rígidas de lenguaje o de visión.

En las últimas décadas, la estrategia de la deconstrucción se introduce en el arte para hacer frente a una nueva necesidad de traducción de la realidad en clave de cuestionamiento a través de la distancia, la ironía, la crítica... Frecuentemente implica claves dispersas, estrategias de seducción, formas abiertas que constantemente remiten a la alteridad retomando lo ya conocido como pretexto. Por otra parte, ha tenido lugar un giro epistemológico relacionado con el papel de la representación de la realidad y el valor otorgado a nuestra experiencia en la cultura contemporánea del consumo. Desde el pensamiento postestructuralista y el anuncio del final de los "grandes relatos", de utopías y de formas ideológicas, se ha enfatizado la discontinuidad entre nuestra realidad y nuestra experiencia. Vivimos en una realidad codificada en las imágenes (para Jean Baudrillard, la posmodernidad ha dislocado cualquier relación directa entre el significante y lo real). Las imágenes son centrales a la cultura de consumo, pero implican relaciones referenciales y discursivas, más que de representación.

La crítica artística post-estructuralista ha interpretado la producción artística posmoderna como una crítica hacia el papel del arte en la cultura occidental y el papel del artista en relación a su obra. Ya hemos de sospechar en la autenticidad de la experiencia, en el genio o la originalidad del artista. El arte parece decirnos que las cosas están agotadas, y que estamos atados a lo que vemos.

A esto hay que añadir una fascinación que Occidente tiene por las réplicas, los duplicados, los dobles y las repeticiones, hasta el punto de responder a lo que se ha llamado la "cultura de la copia" (Schwartz, 1998); vivimos en un tiempo en que más que nunca imitamos/emulamos a nuestros ídolos e iconos de nuestra cultura, a la vez que proliferan reproducciones, maniquíes, marcas, iconos, clones genéticos, etc. En este contexto se hace pertinente reflexionar, también mediante la obra plástica (y la fotografía, en particular), acerca de los problemas de autenticidad, identidad y originalidad.

Como referencia obligada para contextualizar esta idea de réplica, apropiación y reelaboración que vamos a tratar, hemos de mencionar el relato "Pierre Menard, autor del Quijote” (1944). En este cuento, Jorge Luis Borges narra la 8 
peripecia de un escritor de principios del siglo XX que emprende la tarea de escribir El Quijote de Cervantes, letra por letra y sin copiar. Esta empresa delirante de escribir de nuevo la novela de forma idéntica resulta un despropósito, atendiendo a la intención del autor (Menard).

Borges escribe esta historia desde el formato de la reseña literaria, jugando con referencias literarias reales bastante deformadas. Lo que el relato de Borges consigue (entre otras cosas no menos interesantes) es mostrarnos la imposibilidad de que alguien repita el mismo proceso mental y creativo de un autor que inevitablemente pertenece a otro contexto y circunstancia. También Borges evoca la idea de intertextualidad: aceptar el texto como intertexto implica pensarlo, tanto a nivel de escritura como de lectura, en el marco del conjunto textual constituido por la sociedad y la historia. Por eso (desmontando el mito de la originalidad) el texto de Menard, según Borges, sería mucho más rico que el de Cervantes, ya que las configuraciones intertextuales del siglo XX son diferentes a las del siglo XVII.

El autor posmoderno hace literatura de la literatura, y al hacerlo, apunta a que la realidad es un medio para acercarse a la ficción. Borges elabora una concepción del tiempo que le permite hacer de la escritura un acto de lectura. Para él el lector es un ser activo, inmerso, al igual que el escritor, en la productividad del texto.

En realidad "Pierre Menard, autor del Quijote" constituye un verdadero juego textual casi infinito que ejemplifica el límite y el alcance potencial de la tarea de la reelaboración de obras preexistentes. La idea de remake, como más adelante veremos, entra en el juego de esa diferencia, planteando una comparación, una relación recíproca, de forma que uno ilumina al otro, sin que ninguno sea mejor ni peor. Y es que una forma de crear es reescribir; a partir de una base realizada por otro autor es posible crear cosas totalmente nuevas.

\section{La fotografía artística posmoderna: otros usos representacionales}

Después de que la fotografía es finalmente aceptada como práctica artística moderna (con un énfasis en la estética y la impresión cuidada de la imagen), los artistas posmodernos empiezan a plantear otros usos de la fotografía En la posmodernidad se invierten los principios estéticos básicos anteriores, 
apostando por la negación consciente de los principios modernos de la "straight photography”, por una libertad sin escrúpulos y por la subversiva pérdida de respeto al medio: podemos decir que la fotografía es uno de los medios protagonistas en la actividad artística posmoderna, ya que está basada en una serie de paradojas que encajan con las de la posmodernidad, subvirtiendo su presunta naturalidad y autenticidad y haciendo evidente la naturaleza codificada de todo mensaje cultural.

Ante el problema de la lectura de la imagen, han tenido un gran calado las aplicaciones semióticas al estudio de la fotografía. En el análisis del texto fotográfico ha sido fundamental la metáfora del lenguaje y las teorías de autores como Ferdinand de Saussure. La semiótica considera que la fotografía, como en otras formas de expresión visual, es un lenguaje que cuenta con un código subyacente que hace posible la presencia de signos en la imagen, cuya interpretación es necesariamente abierta (Barthes señala que la fotografía es un mensaje sin código).

Hoy estamos condicionados a ver las obras e imágenes fotográficas no como meros objetos, como textos cerrados, separados, autónomos (que existen de forma independiente del ojo que los mira y que, expuestos a la mirada, a la “contemplación”, esperan ser gozados), sino en tanto insertos en el mercado, en el entramado social y cultural. Son obras abiertas que, faltas de originalidad y autenticidad, están expuestas a una comprensión activa, a una re-configuración constante, a múltiples versiones de sí mismas. En realidad, probablemente ni el fotógrafo (el autor), ni la fotografía (el medio), ni el sujeto (el receptor) sean responsables del significado de una fotografía, sino que este significado se produce en el acto de "mirar la imagen", a través de metáforas u otras figuras y de unas ciertas "resonancias". Esto supone un desplazamiento radical del autor, del artista, como principal productor de significado, contradiciendo así al principio moderno anterior, que defendía la obra de arte como un objeto material autónomo, que no hiciera referencia a nada que estuviera fuera de sus propios límites (en un sentido greenbergiano de especificidad del medio).

El impacto central de la posmodernidad en el ámbito de la fotografía consiste principalmente en desestabilizar los vínculos entre representación y realidad. Además, la fotografía tiene la capacidad de cuestionar hábilmente las nociones 
de autoría, originalidad, unicidad, copia, alta y baja cultura, reproductibilidad de la obra de arte, autenticidad y mentira.

Andy Grundberg señala que la fotografía supone una moneda de cambio muy común en el intercambio cultural de imágenes, y debido a ello evita el aura de la autoría que el pensamiento posestructuralista pone en cuestión (Grundberg, 2003:173). Por lo menos, lo hace en mayor grado que la pintura o la escultura, y además está más ligada a la cultura de masas y de producción de imágenes de consumo, de manera que el público está más familiarizado con ella. La fotografía posmoderna se aparta del hermetismo moderno y de la tiranía de la autorreferencialidad (arte sobre el arte, fotografía sobre la fotografía), incluyendo el mundo cultural del cual forma parte: mientras que una de las premisas de la teoría del arte moderno era la insistencia en la autonomía y pureza de la obra de arte, la práctica posmoderna, en cambio, enfatiza la contingencia y primacía de los códigos culturales.

Por ejemplo, en la fotografía "Mount Rushmore, South Dakota" (1969) de Lee Friedlander aparecen unos turistas mirando a través de prismáticos, de pie ante una cristalera que refleja la escena que están contemplando: encontramos una yuxtaposición de planos de realidad visual, de modo que realidad y reflejo se superponen. Esta fotografía ya parece anticipar ideas de pensadores como Baudrillard, en la línea de mostrar cómo la realidad está compuesta de imágenes. De alguna manera, podemos relacionarla con lo que Grundberg (2003:178) apunta: "El arte posmoderno acepta el mundo como una interminable sala de espejos, como un lugar donde todo lo que somos son imágenes, como en el mundo de Cindy Sherman, y donde todo lo que conocemos son imágenes, como en el universo de Richard Prince. No hay lugar en el mundo posmoderno para una creencia en la autenticidad de la experiencia, en la santidad de la visión del artista individual, en el genio o la originalidad. Lo que el arte posmoderno nos dice finalmente es que las cosas se han gastado, que estamos al final de la línea, que somos todos prisioneros de lo que vemos".

Michael Fried apunta directamente a la cuestión de cómo y por qué la fotografía se ha convertido en un modo artístico puntero en el presente. En Why Photography Matters as Art as Never Before (2008), Fried argumenta cómo 
desde los años 70 una fotografía artística seria comienza a ser producida a gran escala y específicamente para ser colgada en la pared del museo o galería, consecuentemente implicando a los autores a centrarse también en la relación entre la fotografía y el espectador que la confronta (colonizando un territorio anteriormente perteneciente a la Pintura). Además, Fried demuestra cómo ciertos problemas filosóficos (asociados con las nociones de teatralidad, literalidad y objetividad, así como con la idea de la intención original en la producción artística) se sitúan en un primer plano en la fotografía reciente. A partir del estudio de trabajos de diversos artistas-fotógrafos actuales (como Cindy Sherman, Jeff Wall, Hiroshi Sugimoto, Thomas Demand, Philip-Lorca DiCorcia, Thomas Struth, Thomas Ruff, Candida Höfer..) Fried explica cómo la fotografía ya no es un lenguaje artístico menor o marginal, sino que directamente entra en la vanguardia del arte contemporáneo como nunca antes lo había hecho, tomando el relevo del Arte (con mayúsculas) no sólo en cuanto a formatos o temáticas, sino también en los contenidos y pretensiones de las obras.

En suma, en la posmodernidad la fotografía cobra un protagonismo singular y se hace especialmente relevante en la tarea de cuestionar las reglas y las estrategias de representación. La fotografía tiene un peso y una presencia singular en la "iconosfera" de la cultura de masas de las sociedades avanzadas, y consecuentemente los autores actuales utilizan con frecuencia el medio fotográfico para plantear preguntas acerca de la problemática de la representación en el contexto sociológico contemporáneo.

Podemos señalar en la llamada "fotografía tras la fotografía artística" un nuevo interés por el referente, ahora entendido no como algo dado, sino como problema. Verdaderamente, la fotografía supone una instancia crucial en el presente, atacando las nociones de subjetividad y originalidad y centrándose en cuestiones relativas a los conceptos de autoría, unicidad, simulación, estereotipo, posición social y/o sexual del objeto de observación e incluso del propio sujeto que observa. Viene inequívocamente ligada a algunos dispositivos fundamentales tales como serialidad, repetición, apropiación, intertextualidad, simulación, pastiche, y, como a continuación expondremos, funciona además como un medio idóneo para desarrollar estrategias como el "remake”. 


\section{El concepto de "remake". Definición, características, actitudes}

"Remake", palabra anglosajona aceptada y entendida popularmente, significa "hacer algo otra vez, o de forma diferente". En el ámbito de la creación visual, la estrategia representacional y narrativa del remake activa el papel de nuestra memoria colectiva en la lectura y aportación de significado de la imagen, que cobra una nueva dimensión de profundidad al articular dos planos de significación: el de denotación de lo contado y el de connotación de algo de nuestra cultura que de repente se infiltra en la historia particular. Cuando nos encontramos ante un remake tenemos la sensación de estar ante algo que ya hemos visto $\mathrm{u}$ oído antes, nos viene a la cabeza una otra situación, produciéndose una especie de dèja-vu².

Un remake no ha de ser simplemente mirado o visto: ha de leerse como un texto, y ha de leerse también su arquitectura, las fuerzas y modelos que lo rigen, descifrando los códigos que lo constituyen, a los que se sujeta o resiste. Para Barthes (2002) el "texto" no es un "objeto", sino un "espacio" entre el objeto y el lector/espectador. La noción de intertextualidad del remake estaría relacionada con los ámbitos de lo que Barthes llama lo "déja-lu" (lo "ya leído/ ya visto"), y todas las evocaciones "accidentales". En este sentido, se hace imposible una "suma" de significados, ya que la imagen final que resulta es muchas veces un "todo contradictorio".

En el remake encontramos, en cierto modo, un "inconsciente óptico", utilizando una terminología de Benjamin³ (1935) sobre la que Rosalind Krauss (1997) ha reflexionado ampliamente4 . José Luis Brea (2007: 146) relaciona este término con la hipótesis de que "hay algo en lo que vemos que no sabemos que vemos, o

\footnotetext{
2 El dèja-vu, término francés que se traduce como "ya visto", se emplea para describir la experiencia de sentir que se ha sido testigo o que se ha experimentado previamente una situación nueva.

3 En su ensayo "La obra de arte en la era de su reproductibilidad técnica" (1935), Walter Benjamin propone el concepto de "inconsciente óptico" para referirse a las dimensiones que pasan desapercibidas al ojo consciente educado en la civilización de la representación. La fotografía y toda otra serie de dispositivos tecnológicos hacen posible la percepción de aquello que no puede ser visualizado de otra forma. De este modo, gracias a estas mediaciones técnicas, se hace visible lo no visible y lo no visto se integra al imaginario.

4 El "inconsciente óptico" de Rosalind Krauss funciona como una protesta contra la historia oficial de la modernidad y contra la tradición crítica que intentó definir el arte moderno. Con este término, Krauss se refiere a una fuerza desobediente, disociadora, que persistentemente frecuentó el campo de la modernidad desde los años 20 a los 50, y cuestiona la autonomía normativa de la racionalidad visual.
} 
algo que conocemos en lo que vemos que no sabemos "suficientemente" que conocemos".

El remake se presenta bajo la forma de algo que no es nuevo, como un modo de volver eternamente a lo mismo. Pero de alguna manera, opera transformando, revisando, reinventando, reconstruyendo continuamente de una forma instintiva e inevitable a veces; otras, de manera deliberadamente intencionada, con fines más poéticos, metafóricos, perversos... El remake no sería una mera copia, sino escritura, inscripción cultural; tiene un carácter construido. Llegamos a conocer y conectar con la imagen en cuestión no sólo por medio de intuiciones, sino también gracias al lenguaje y el referente de la imagen, entendida como un sistema de signos y de significación que funciona mediante tropos, y no como un conjunto establecido de significados.

Podríamos decir que la creatividad artística es, en cierto modo, limitada, y si nos referimos al trabajo de contar historias o comunicar conceptos, encontramos que puede darse una combinatoria casi infinita a partir de diversas variables... Y en realidad los temas sobre los que hablar, los temas que acaso nos interesen realmente por ser temas que hablan de nuestra propia condición humana, son básicamente constantes: siempre, de alguna manera, giramos alrededor de unos cuantos problemas existenciales que nos afectan a todos en mayor o menor medida (antes, ahora, o luego), unas cuantas pasiones, unos cuantos miedos, unas cuantas tragedias vitales... El remake se infiltra en la existencia de las cosas, y supone una técnica narrativa que consiste, básicamente, en repetir nuestros pasajes preferidos para llegar a otros lugares. "Remake" significaría literalmente rehacer, hacer de nuevo algo que ya está hecho. El término ha sido utilizado para definir aquellas versiones de creaciones que ya existen, pero que son utilizadas como punto de partida para hacer obras nuevas.

En sus series de documentales para la BBC "Ways of Seeing” (1972), John Berger nos habla del potencial que las imágenes de la Historia del Arte, al ser reproducidas en otros medios, pueden tener, en tanto que pueden ser vistas y usadas de otros modos. Las obras de arte tienen siempre algo misterioso, ambiguo; el significado de una imagen puede transformase dependiendo de cómo la veamos, qué la precede, qué le sigue, esto es, en qué contexto se 
muestra. John Berger nos anima a plantear miradas diferentes en relación a las obras de arte clásicas, y también a usarlas como medio de comunicación. Al igual que normalmente empleamos palabras para la comunicación, es posible emplear también imágenes para decir cosas, adaptándolas a nuestros propósitos. Con las imágenes también hablamos, y en ocasiones puede resultar interesante y saludable "perderles el respeto", combinándolas en otras narrativas, insertándolas en otros contextos o campos de conocimiento para darles una nueva vida, no restringida por nuestra mistificación de esas imágenes como reliquias del arte, intocables e inaccesibles.

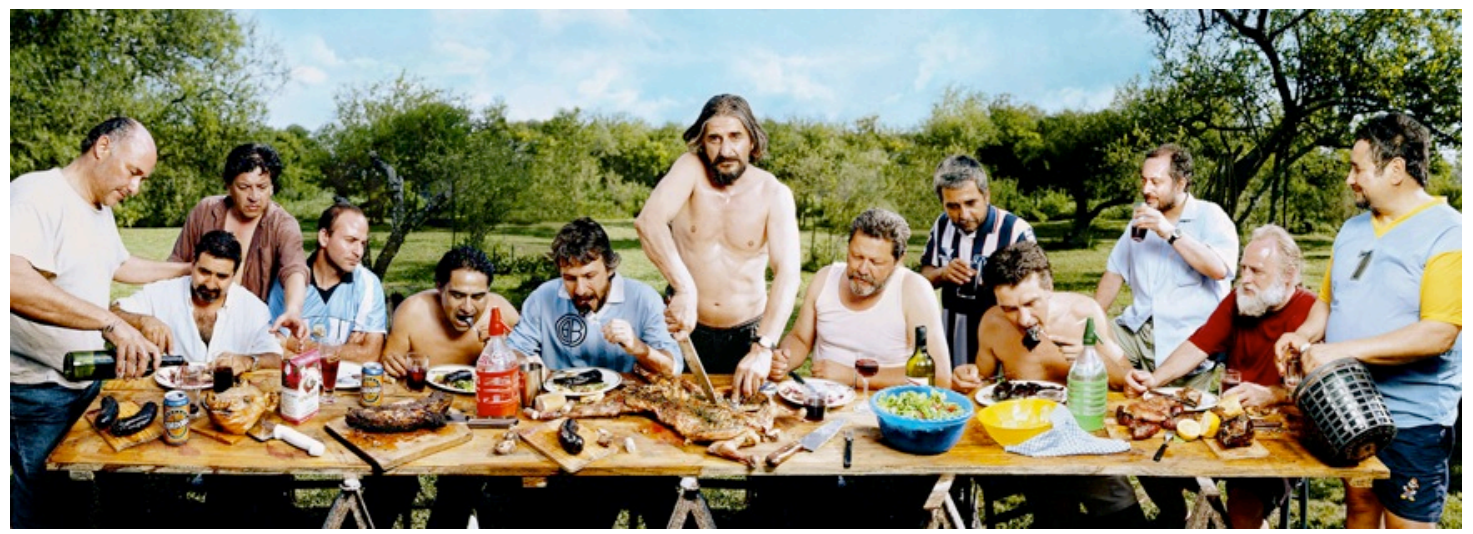

Imagen 2. Marcos López: “Asado en Mendiolaza, Córdoba, Argentina” (2001)

En el campo de las artes plásticas, esta propuesta de nuevas miradas a lo cultural encuentra un aliado ideal en la estrategia del remake. Ésta puede abarcar prácticas discursivas muy diferentes, contemplando el apropiacionismo, el pastiche, la paráfrasis visual, la deconstrucción, la alegoría.

Entre el homenaje y la copia, el remake implica frecuentemente una cierta burla o cuestionamiento de la originalidad, que tradicionalmente ha definido (junto con otros términos un tanto obsoletos como inspiración, talento, o virtuosismo) lo que se entendía como uno de los atributos de un artista. En este sentido, el remake se hace cargo de problemáticas posmodernas acerca de la autoría, originalidad, derivación, y autenticidad artística. Estos conceptos han sido subvertidos en grandes obras de arte y de literatura desde hace siglos. Por ejemplo, a menudo la gente se sorprende cuando descubre que Shakespeare obtuvo gran cantidad de su material de otras fuentes, en ocasiones simplemente 
reescribiendo historias sin molestarse en disfrazarlas o disimularlas. Podemos preguntarnos si realmente importa esto. Bien, si consideramos que aún así todavía hoy consideramos a Shakespeare como uno de los más grandes escritores de la historia (y que los contenidos de sus obras nos siguen pareciendo universales), la respuesta puede ser no.

En el libro Remediation: Understanding new media (Bolter/Grusin, 2000) se considera el tópico de la revisión y la repetición en un sentido más amplio, en un enfoque que resulta muy interesante adoptar (se trata de un tópico que necesita actualizarse en los términos relativos a nuestra sociedad contemporánea, saturada por los media, Internet, imágenes digitales, y por supuesto, fotografía). Walter Benjamin habla del concepto de "aura" en relación a la autenticidad y el valor artístico. Básicamente, según Benjamin (1973) si el arte puede ser y es fácilmente reproducible, pierde su aura y por tanto, su valor (y la fotografía sería una herramienta preeminente para llevar esto a cabo). Sin embargo, encontramos que los artistas que emplean el remake no se limitan a reproducir obras de arte anteriores de una manera idéntica, y los procesos creativos que desarrollan a partir de los originales dotan a las imágenes de una nueva "aura" asociada a otros medios.

Hoy encontramos incontables artistas que trabajan puntual o sistemáticamente en este ámbito de la reconstrucción. Concretamente, la fotografía (como veremos) se ha valido de la iconografía pictórica, apropiándose a veces de cuadros famosos; también de elementos del mundo del cine, de la literatura, de la mitología, de los arquetipos culturales.... En realidad nos enfrentamos a unas mismas historias en forma de capas de significación en las que el estrato último será sólo apariencia de origen. Al habitar el texto, se subvierte un tiempo narrativo donde no hay principio ni final, donde es difícil definir dónde acaba lo universal y dónde empieza lo particular.

El ejercicio del remake está también relacionado con la simulación, con la proliferación de simulacros (Baudrillard, 2008), de creaciones fantasmagóricas que evocan objetos que no siempre podemos identificar. Su existencia misma 


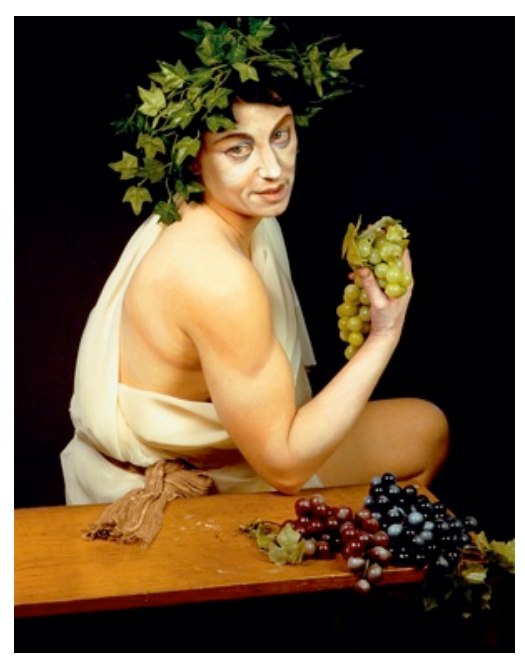

interioriza una desemejanza, deshaciendo la propia posibilidad de una visión icónica definida e identificable con seguridad. El auténtico remake trabaja desde el interior del icono, lo transforma, lo convierte en algo que siempre tiene algo de distinto y de nuevo.

Imagen 3. Cindy Sherman: "Untitled \#224” (1990)

\section{El remake en la fotografía escenificada}

Posiblemente estemos viviendo en el período que pasará a la historia como el momento de mayor auge de los remakes, innumerables a través de apropiaciones, repeticiones, copias, revisiones y citas, poniendo en tela de juicio el concepto de "originalidad". Nuestra cultura es una cultura de citas, de notas aclaratorias, donde los territorios se mezclan y se cancelan, una época del reciclaje infinito, donde las historias se configuran por capas. Y esta pulsión de revisión encuentra en la fotografía construida o escenificada un lenguaje singularmente apropiado.

La práctica de copiar grandes obras de arte ha sido la forma tradicional en la que los estudiantes aprendían de los viejos maestros. Dada la dificultad de trabajar directamente con los originales, generaciones de estudiosos han confiando en las reproducciones. Pioneros fotográficos como William Henry Fox Talbot comprenden la utilidad de la fotografía como herramienta educativa; él esboza sus propuestas en una publicación seminal, The Pencil of Nature (1844-1846), uno de los primeros libros con ilustraciones fotográficas.

Oscar Gustav Rejlander vislumbra otras posibilidades innovadoras. Como artista, comienza a trabajar copiando pinturas para la reproducción litográfica, y en 1853 aprende el proceso fotográfico a través del asistente de Talbot. Desde aquel momento, entiende que la cámara le ofrece un modo completamente original de "copiar" obras de arte, fotografiando tableaux escenificados de pinturas. En un principio, el propósito de Rejlander es educativo. Su obra "Two 
Ways of Life" (1857) re-escenifica la composición de Rafael en la pintura "La Disputa del Sacramento" (1509-1510), pero con un asunto diferente: la obra de Rejlander tiene un contenido alegórico y moralizante propio de la época victoriana. Por otro lado, su "Young Woman in Prayer" (1858-1860) es una cuidadosa recreación de "La Virgen rezando"(1640-1650), del pintor del siglo XVII Sassoferrato. Al parecer, la intención última de Rejlander en estas obras no es simplemente rendir un homenaje a los artistas que admira o facilitar la enseñanza artística, sino mostrar que la fotografía puede también cumplir con la seriedad artística del dibujo o la pintura.

En una línea similar, Rejlander produce la obra “The First Negative”, inspirada en la historia de Plinio acerca de los orígenes del dibujo y la pintura. Aunque este asunto es descrito en la pintura desde el siglo XVIII, supone el primer intento de Rejlander en contar una historia comprimida en una fotografía. Mientras que "Two Ways of Life" (su obra más célebre) o "The First Negative" hacen referencia al período clásico a través de los ropajes o las narrativas, otras fotografías escenificadas victorianas son directamente copiadas de obras de arte clásicas.

Más tarde, el italiano Guido Rey y el holandés Richard Polar producen fotografías basadas en el estilo y las maneras de Johannes Verneer, Pieter de Hooch y otros pintores flamencos. Algunos pictorialistas 5 continúan partiendo de pinturas para elaborar sus contenidos incluso en la década de 1930 (por ejemplo, encontramos "Flemish Maid" de William Mortensen, en 1935). La práctica de fotografiar escenas inspiradas en obras de arte continúa en el siglo XX, convirtiéndose en una de las marcas distintivas del Pictorialismo. Este estilo lucha por establecer un lugar para la fotografía en el arte, intentando diferenciarla de los trabajos fotográficos comerciales mediante la emulación de formas de arte más establecidas, como la pintura.

A partir de la entrada en la posmodernidad, encontramos un creciente número de ejemplos de la práctica del remake en la fotografía. En esta época, que da la bienvenida a todo tipo de reciclajes, pastiches, recombinaciones $\mathrm{y}$

5 El Pictorialismo es una corriente fotográfica (la primera de pretensiones artísticas) que surge entre finales de los años 1880 y el final de la Primera Guerra Mundial en Europa, Estados Unidos y Japón. Los pictorialistas se distancian de la realidad con una voluntad de que sus fotografías sean sólo imágenes y no meras reproducciones. El movimiento se caracteriza por ideales románticos, mensajes narrativos o alegóricos, y convenciones gestuales y estéticas pictóricas. 
deconstrucciones, esta estrategia se vuelve recurrente, especialmente en el campo de la fotografía escenificada o construida. En este tiempo de desencanto e ironía a partes iguales, se vuelve (a veces de forma irreverente) a las fuentes para elaborar productos nuevos, que ya no son meros ejercicios de estilo ni rendidos homenajes a los originales, sino dispositivos que pueden conducir a desenlaces muy diferentes. Una de las características que introducen los artistas posmodernos en el ejercicio del remake es precisamente esta "pérdida de respeto" a las fuentes. Ya no se hace necesariamente eco de las ideas y contenidos de las obras de las que se parte (o a las que se llega), sino que se subvierten estas narrativas, introduciendo relatos, valores o conceptos nuevos.

Entre los asiduos a esta práctica fascinante, sobresalen Cindy Sherman y Yasumasa Morimura. El trabajo de Sherman destaca, entre otras cosas, por su utilización de manierismos que evocan fotogramas cinematográficos, fotografía de moda, pornografía y pintura; en muchos aspectos, es el ejemplo por excelencia de la posmodernidad fotográfica. De alguna manera, su carrera y su obra encarnan el impacto del pensamiento posmoderno en el mundo del arte y la utilización de la fotografía y sus técnicas mass-mediáticas como medios de expresión artística. Podríamos decir que a partir del reconocimiento que la crítica empieza a hacer de sus fotografías de la serie "Untitled Film Stills" en los años 70 (con la apropiación de pastiches y tipos visuales genéricos) se desata la práctica abierta del remake fotográfico actual.

Como Rosalind Krauss (1993) argumenta, Sherman plantea unos intentos desestabilizadores para diseccionar la formación y la percepción de imágenes que convierten a sus obras (y a ella misma) en iconos del pensamiento feminista (y de otras corrientes). Krauss explora en profundidad los diferentes enfoques de filósofos e historiadores en relación al trabajo de Sherman, y se pregunta si tal vez han perdido demasiado de vista la imaginería en sí misma, o más específicamente, la manera en que las imágenes son construidas. Sherman rehace iconos anónimos (en los "Untitled Film Stills") que no podemos encuadrar con seguridad en alguna película concreta, pero que forman parte de un imaginario cinematográfico y cultural en el que los roles de las mujeres son marcados y esterotipados: la artista los analiza autorretratándose sin realmente representarse a sí misma (en una idea de “muerte del autor”). 
Pero también reconstruye imágenes de cuadros paradigmáticos de la Historia del Arte. En 1977 Cindy Sherman comienza a producir una serie de remakes de pinturas clásicas (a veces cuadros singulares reconocibles, como en el caso de "Untitled \#224" (1990), que reelabora la pintura barroca "Baco Enfermo" (1593-94) de Caravaggio, y a veces de cuadros que reconocemos como retratos de género de la pintura clásica, de una manera más indeterminada). La autora se caracteriza específicamente para cada caso, empleando un sofisticado atrezzo y maquillaje en una idea muy cercana a la mascarada y a lo casi grotesco, explotando las implicaciones de la máscara y los disfraces hasta el ámbito de lo surreal, lo feo, lo artificial y lo extremo. Sherman, en piezas como ésta, encarna el concepto de remake al que nos referimos, ya que transforma radicalmente las obras que reelabora, apuntando a direcciones muy alejadas del original a través de contenidos que conectan con una sensibilidad del presente. Krauss sugiere que desvelando lo obsceno (lo que debiera quedarse fuera de escena) y lo grotesco cotidiano en las representaciones artísticas de mujeres, Sherman subvierte (de un modo perverso) las convenciones aceptadas de la mujer como objeto genérico y no-masculino de la mirada. La artista examina y expresa su disgusto a través de la utilización de lo desagradable, tomando la tradición para ejemplificar su protesta.

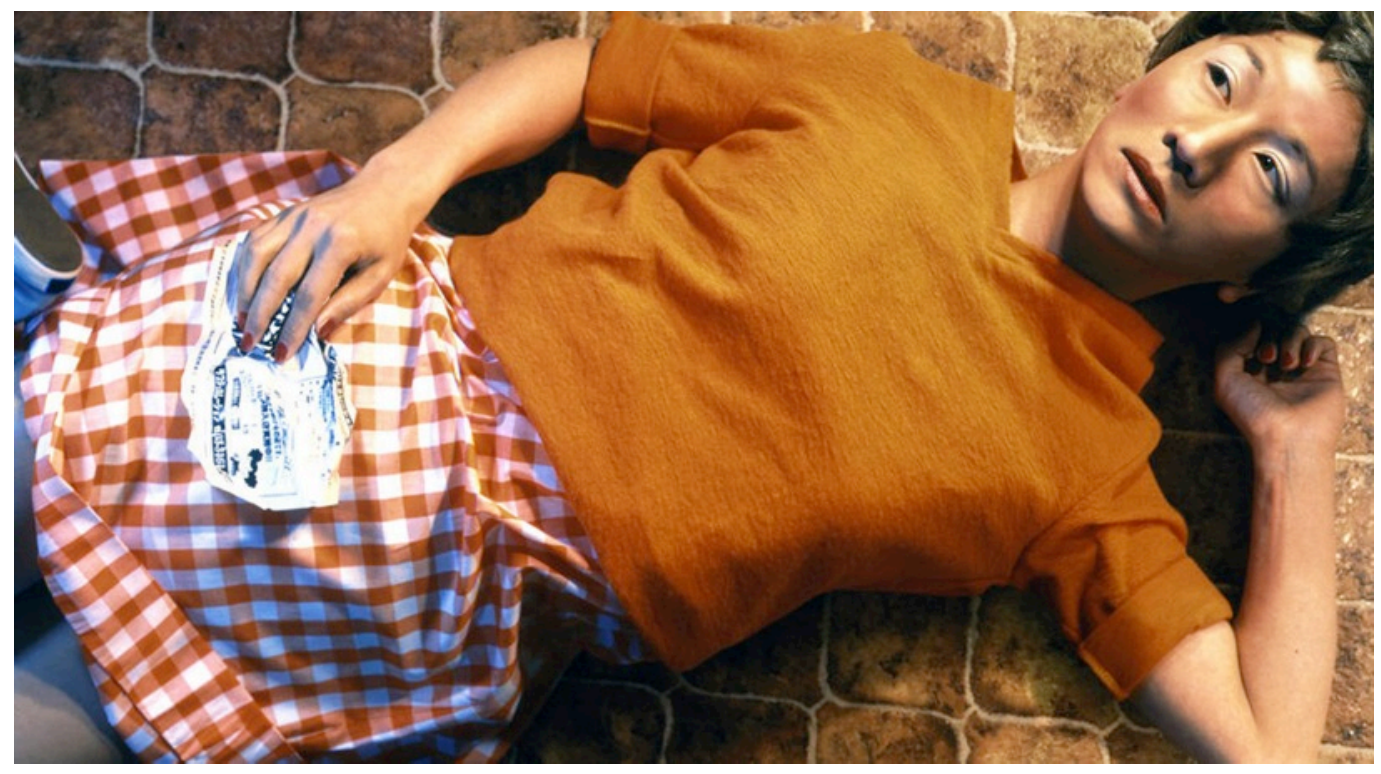

Imagen 4. Yasumasa Morimura: "To My Little Sister: For Cindy Sherman” (1998) 
Yasumasa Morimura comparte con Sherman la afición por el autorretrato y la disolución del autor en lo representado, y en su caso esta práctica además apuesta exclusivamente por el remake de pinturas clásicas de la Historia del Arte: encontramos imágenes que reelaboran la Olympia de Manet, la Gioconda, o pinturas de Frida Kahlo. En un primer vistazo son imágenes engañosas, ya que instintivamente reconocemos estos iconos. Sin embargo, al segundo vistazo, nos damos cuenta de que la cara de los personajes retratados es siempre

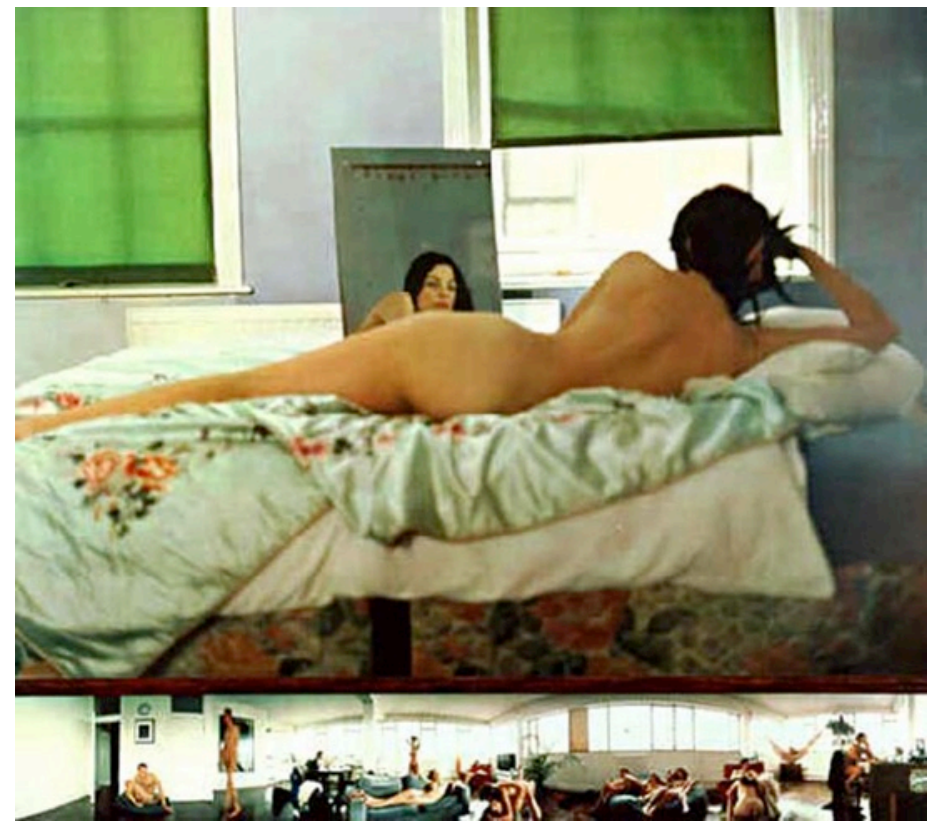
la de un hombre (ambiguo, pero un hombre) japonés, el propio Morimura. Como curiosidad, hay que señalar que el autor incluso hace un guiño abierto a Sherman cuando realiza su obra "To My Little Sister: For Cindy Sherman” (1998), un remake del "Untitled \#96" (1981) de la fotógrafa.

Imagen 5. Sam Taylor-Wood: “Soliloquy III” (1998)

El remake vertebra algunos trabajos de Sam Taylor-Wood.“Soliloquy III” (1999) parte directamente de la famosa "Venus del espejo" de Velázquez, esta vez inmersa en un pensamiento íntimo y fantástico, de connotaciones abiertamente eróticas. También en "Wrecked" (1996), donde revisa el cuadro de "La última cena" de Leonardo para introducir una mirada feminista, Taylor-Wood sustituye la figura de Cristo por la de una mujer desnuda que se ofrece como alimento a un grupo de hombres, planteando una potente metáfora. En relación a este tema, también hemos de mencionar las "últimas cenas" de Anthony Goicolea (en este caso, sin una figura de Cristo, recreando el eterno adolescente clonado del artista devorando sandwiches de pan Bimbo) o la de Marcos López, que describe con humor una prosaica churrascada criolla en su contexto local (Argentina). 


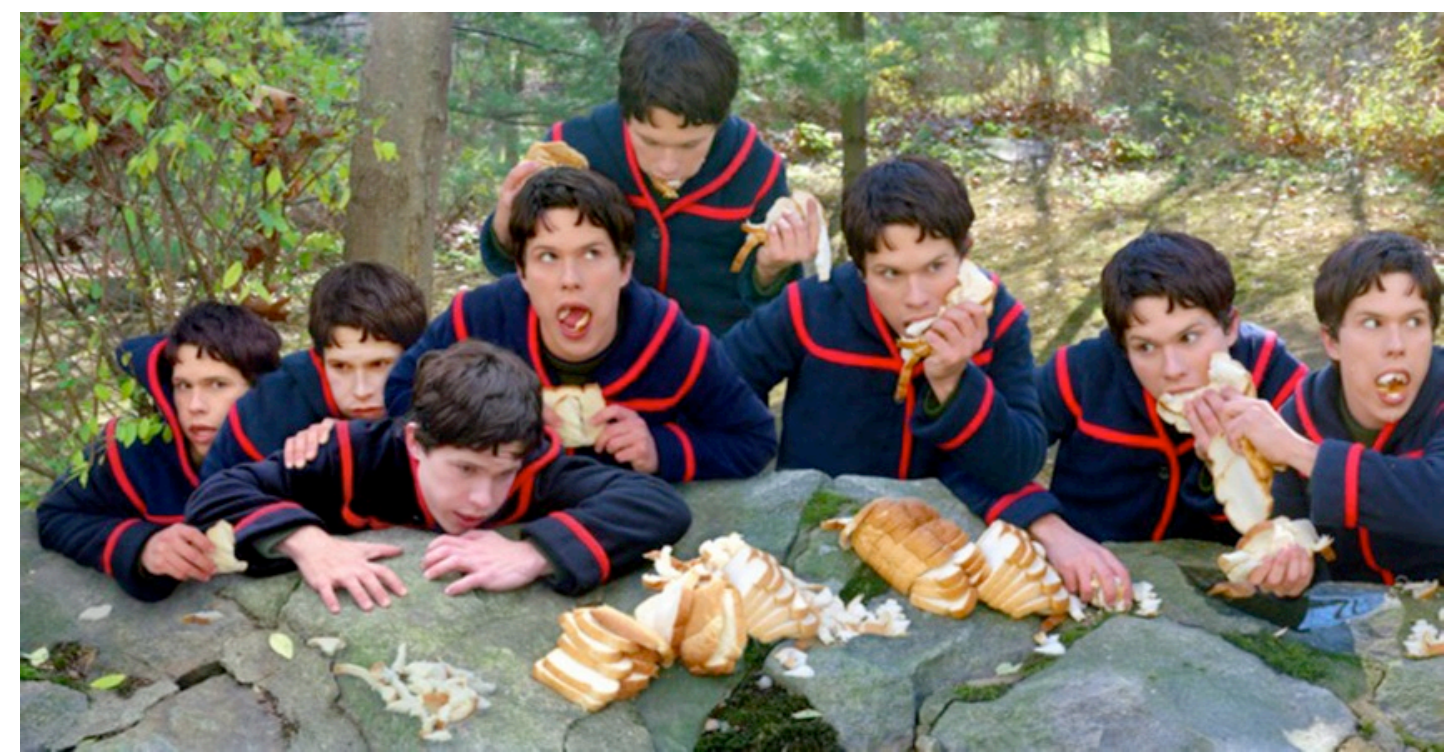

Imagen 6. Anthony Goicolea: “The Last Supper" (1999)

Hoy en día podemos apreciar esta consistente apuesta por el pastiche de la gran pintura, en un sentido de reciclaje a veces cómico, a veces crítico también. David LaChapelle revisando imágenes paradigmáticas de la Historia del Arte o la cultura popular (realiza una controvertida imagen de una "Pietá" miguelangelesca encarnada por la "viuda del grunge" Courtney Love con un modelo muy parecido a Kurt Cobain en su regazo), o Pierre and Gilles con sus iconos kitsch basados en beaterías e iconos religiosos diversos, son ejemplos de cómo a través de una estética que bebe directamente de pinturas célebres y referencias pictóricas clásicas es posible presentar contenidos contemporáneos. Con una mayor afinidad a la Pintura que a la fotografía muchas veces, y apuntando a materias frecuentemente sacadas de obras de arte, estos fotógrafos emplean un vocabulario derivado de la Historia del Arte, contaminado de otros elementos de la cultura visual como la publicidad, la moda o el cine.

Jeff Wall es una obligada referencia acerca de un enfoque particular de la idea de remake contemporánea. Wall constantemente revisa obras de arte famosas en sus "pinturas de la vida moderna", dotándolas de una nueva dimensión de significado, comprometido con algo de la realidad social histórica y puntual del artista. En obras como "The Storyteller" recupera el famoso posicionamiento de figuras del "Almuerzo sobre la hierba" de Manet; otra vez, Manet en su "Picture for Women"; un grabado clásico de Hokusai fielmente reelaborado en "A Sudden Gust of Wind (After Hokusai), esta vez jugando con la metáfora de lo 
fácil que puede resultar "perder los papeles" en una sociedad que todo parece tener controlado pero que en fondo está constantemente en equilibrio frágil, a punto de derrumbarse...

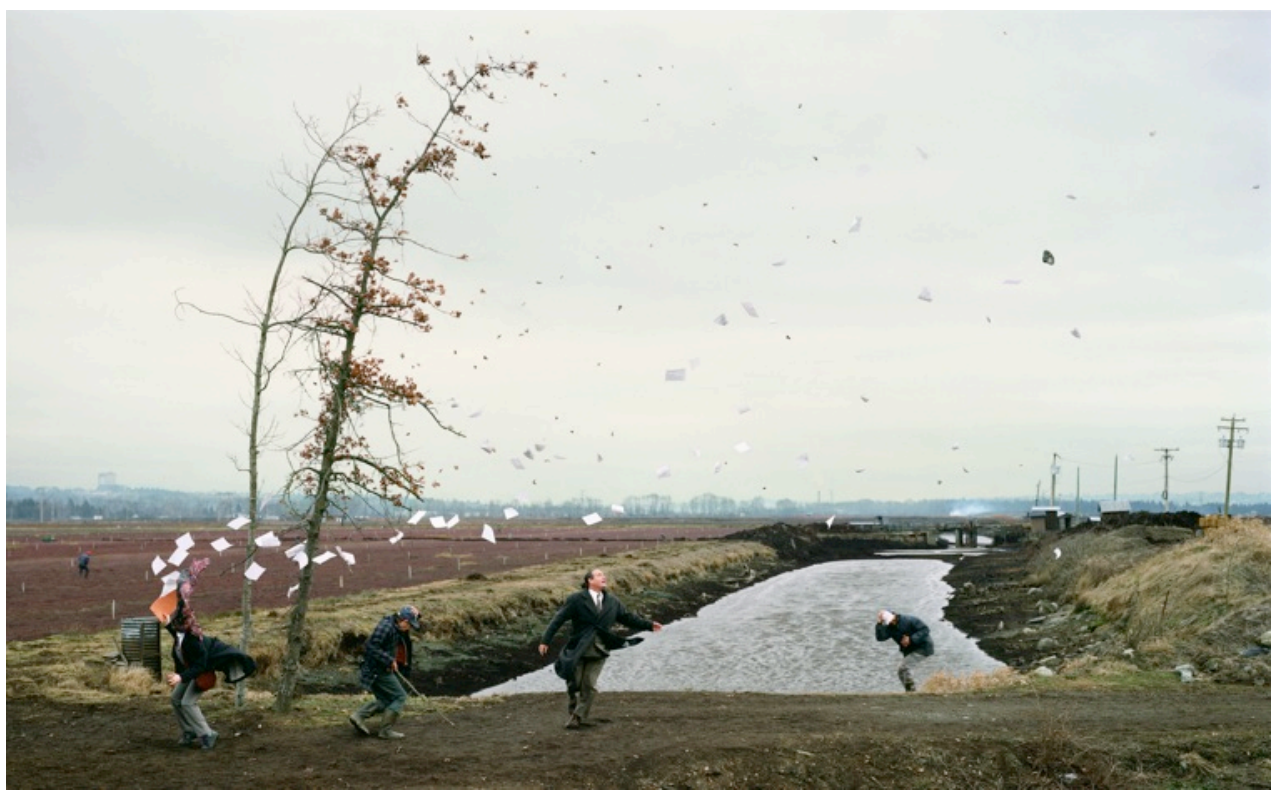

Imagen 7. Jeff Wall: “A Sudden Gust of Wind (After Hokusai)” (1993)

Jeff Wall lleva más allá la estrategia del remake, dándole un giro de tuerca. Como artista paradigmático de la estrategia de deconstrucción, Wall acepta que las cosas están construidas (mal construidas) a base de representaciones rígidas y estereotipos. Jean-François Chevrier (1996:11) apunta que "un aspecto significativo del trabajo de Wall es la aceptación de la noción de que la lucidez crítica (una aproximación conceptual y dialéctica) puede participar en la retórica de la ambigüedad, de acuerdo con el "manierismo" que emergió del Pop Art de los sesenta (...). Pero la parodia permite sólo la apropiación de fragmentos de la tradición pictórica, mientras Jeff Wall propone una reconstrucción sistemática”. Y es que Wall en ocasiones echa mano de diversas paráfrasis de tipologías visuales, estructuras formales estéticas o arreglos espaciales de ejemplos de la Historia del Arte, pero lo que hace es transformar su sustancia iconográfica y, combinándola con el presente, crear constructos enteramente nuevos. Sus trabajos no son tanto composiciones como constructos ensamblados de varias realidades. Lejos de funcionar como mera 
repetición, estos constructos se conforman como nuevos dispositivos de reflexión y análisis, funcionando como "imágenes dialécticas"6.

Una imagen-remake de Wall perfectamente dialéctica es “The Storyteller" (1986), probablemente una de las mejores obras del autor. Una imagen dialéctica ha de presentar algún dualismo, y como brillantemente analiza Thierry de Duve (2004), en “The Storyteller” los dualismos se multiplican. En la imagen, la posición del grupo de tres personas que encontramos en un lado de la imagen nos recuerda inmediatamente al "Almuerzo sobre la hierba"7 (1863) de Manet, lo cual desencadena una serie de interrogantes y asociaciones acerca de la identidad y actividad de los personajes, y de por qué esa imagen de referencia aparece invertida, o de por qué entendemos esa fotografía como un cuadro.

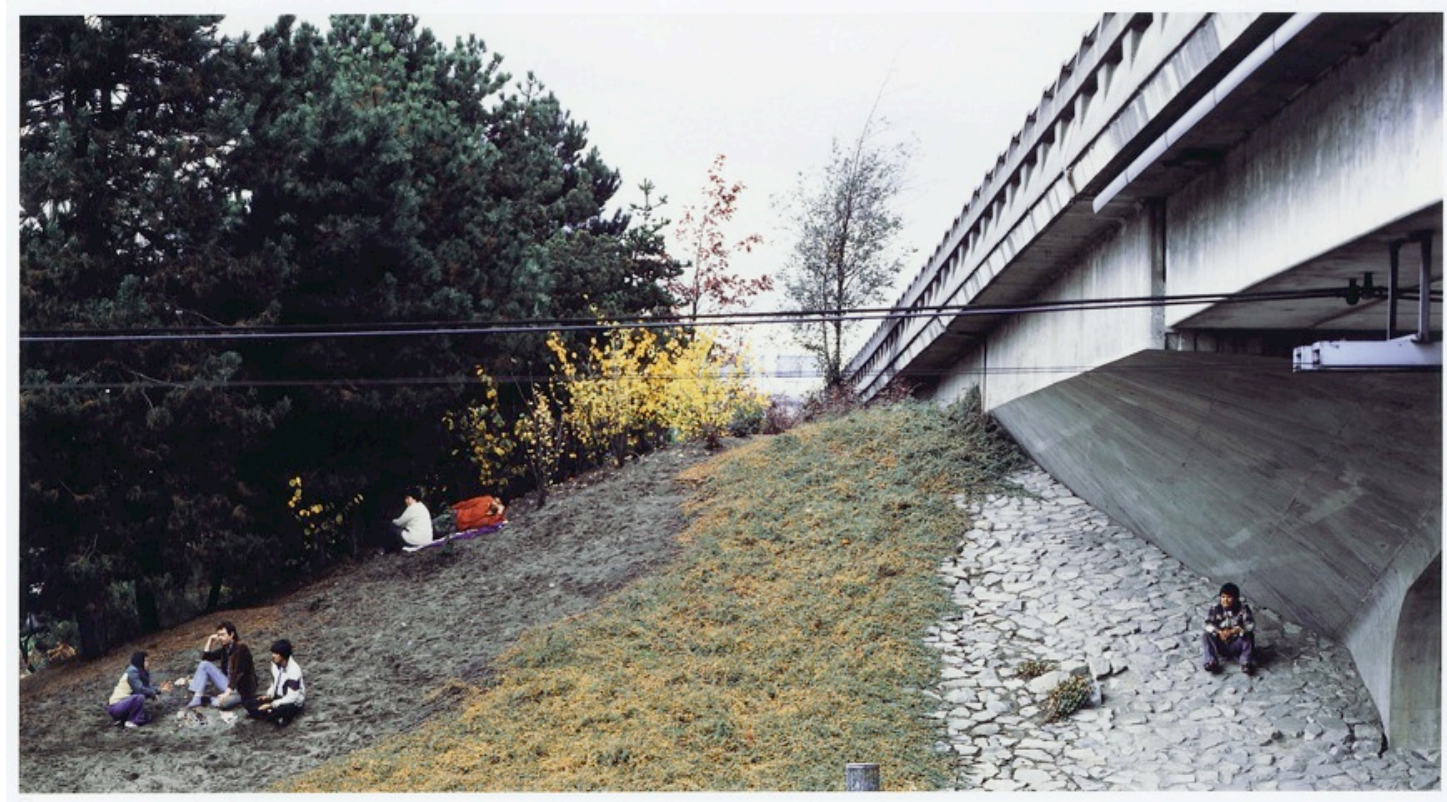

Imagen 8. Jeff Wall: “The Storyteller” (1986)

\footnotetext{
${ }^{6}$ Walter Benjamin hablaba de la "imagen dialéctica" como una imagen que brilla, una imagen del pasado que puede fulgurar en el momento actual, posibilitando conocimiento. La imagen dialéctica puede operar como instrumento para una lectura crítica de la Historia, esto es, como el conversor de una narración ajustada a patrones particularistas y monocordes en una constelación en tensión constante ("Tesis de la filosofía de la historia" (1940), en Discursos interrumpidos I. Filosofía del arte y de la historia (1989). Madrid:Taurus).

7 El "Almuerzo sobre la hierba" de Edouard Manet agrupó los géneros de retrato, paisaje, y naturaleza muerta en una sola imagen, integrados bajo la unidad del plano pictórico.
} 


\section{El remake fotodramático actual. Particularidades y artistas}

Podemos decir que vivimos en un momento de "post-fotografía", donde la fotografía propugna la superación de la imagen como icono indicial y su dilatación hacia otros campos: hoy en día la fotografía ya no existe como un medio puro, específico y delimitado, sino como un medio híbrido que acoge otros planteamientos expresivos, intenciones y preocupaciones. Una vez superada su anterior condición esencialmente documental y alcanzado un grado de sofisticación tecnológica, ha surgido todo un nuevo mundo de posibilidades creativas. La fotografía se hace pictórica, teatral, instalativa, performativa, discursiva... Ya no bebe sólo de los hechos reales, e incluye entre sus prácticas también el montaje, el reciclaje y el remake de imágenes, incluso de otras imágenes fotográficas. Nuestro imaginario colectivo está basado en imágenes que absorbemos continuamente, no en visiones reales obtenidas empíricamente. En este contexto, el remake es una de las estrategias narrativas preferidas por muchos autores de la fotografía construida/escenificada en la actualidad.

Se ha criticado a menudo la pérdida de intensidad de muchas imágenes actuales, la levedad de los personajes frente al peso dramático de los personajes de los referentes originales. En esta vertiente negativa la práctica del remake ha sido criticada por estar a veces cercana a una estética de "corta y pega": es cierto que dentro del panorama actual proliferan ejemplos de tácticas simplistas convertidas en fórmulas que sustituyen el talento y el compromiso artístico (lo vemos en la música, la televisión, el cine, la moda, y por supuesto, también en la fotografía). Sin embargo, en su vertiente positiva, el remake fotográfico hoy en día genera una gran cantidad de reflexiones valiosas y de revisiones productivas

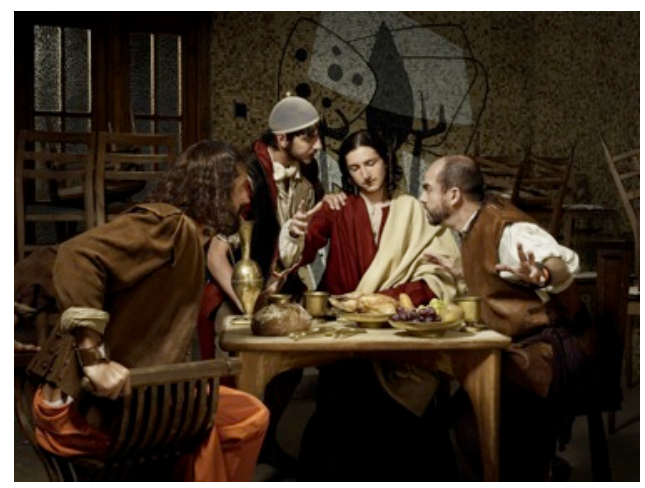
de obras clásicas. En el ejercicio del remake sin duda cabe (y es necesaria) una reflexión irónica y lúcida sobre la manera en que manejamos nuestra memoria histórica $\mathrm{y}$ artística. Encierra frecuentemente una dimensión crítica, anti-utópica, espectacular.

Imagen 9. Erwin Olaf: “Cena en Emmaus” (2008) 
Un buen número de artistas "fotodramáticos" (esto es, autores que utilizan la fotografía construida o escenificada como lenguaje, incluyendo disposiciones teatrales y poses diseñadas para la cámara) nos proponen en sus imágenes guiños culturales (artísticos, históricos, mitológicos, cinéfilos...), a modo de una especie de samplers que se activan de repente. Éstos pueden ser actos agresivos, insolentes a veces, que no responden necesariamente a jerarquías: se pierden y se diluyen las referencias concretas históricas y las ideologías de origen, dando la bienvenida a otros significados. Acaso hoy estemos, en gran medida, condenados a trabajar con mitologías de segundo o tercer grado.

El sampler funciona, por un lado, como una herramienta intertextual (en tanto que introduce ideas o imágenes preexistentes, planteando relaciones entre dos o más dimensiones), y por otro, como un mecanismo más o menos perverso (en el sentido etimológico de la palabra) mediante el cual los artistas, productores culturales, juegan con nuestro conocimiento y nuestra base visual introduciendo lógicas diferentes. Algunas veces encontramos ejemplos de utilizaciones narrativas de estos samplers en los trabajos de artistas que operan jugando con diferentes lenguajes, imágenes procedentes de distintas fuentes, proponiendo cambios de texturas, arquetipos y géneros. El sentido de reciclaje se explota más que nunca: se dan usos nuevos a imágenes y conceptos “viejos”, despojándolos a veces de ideologías arcaicas, o aprovechando la vigencia de muchas de las cuestiones que plantean.

El remake, en cierta manera, viene a ser una forma aparatosa del sampler, y tiene en cuenta que el espectador tiende a querer ver aquello que ha visto antes, aquello que es capaz de reconocer: se hace ideal este equilibrio entre la novedad y el reconocimiento. Los autores fotodramáticos, como a continuación veremos a través de algunos ejemplos, parecen estar diciéndonos que el sujeto contemporáneo no existe, y que hay un limbo de arquetipos que hoy pueden vivir en constante cortocircuito.

Dentro de la tendencia del remake en la fotografía artística actual, hemos de mencionar la relevancia de la exposición “Acting Out: The Invented Melodrama in Contemporary Photography"8, comisariada por Kathleen A. Edwards. Los

8 "Acting Out: The Invented Melodrama in Contemporary Photography" fue comisariada por Kathleen A. Edwards y mostrada en el Neuberger Museum of Art (Purchase, Nueva York, EEUU) del 5 de 26 
artistas de la muestra tienen en común que, con diferentes estrategias, diseñan y construyen cuidadosamente sus fotografías, a modo de directores de cine.

La idea de apropiación había comenzado años antes, introducida en las prácticas de autores como Cindy Sherman, Sherrie Levine o Richard Prince, concebida como modo de "interrogar" a las imágenes que nos rodean y nos condicionan. Luego, la idea de apropiación penetraría ampliamente en nuestra (alta y baja) cultura, convirtiéndose en una cierta marca de nuestros tiempos. En “Acting Out” la idea de remake está infiltrada casi inadvertidamente; la exposición toma esta idea con finura, mediante la apropiación de iconos e historias de un modo particular, empleando la escenificación fotográfica (que Sherman venía haciendo desde los años 70) para evocar crípticamente estereotipos cinematográficos. Uno de los logros (acaso inintencionados) de esta muestra es proponer la fotografía escenificada como una especie de pintura prerrafaelita de nuestro tiempo, reconstruyendo imágenes anteriores (pertenecientes a la cultura mediática, al melodrama, a la telerrealidad, a la publicidad o a la propia historia de la fotografía) aparentemente pasivas e intelectualmente obvias, plagadas de un sentimentalismo fingido.

Entre los autores de la muestra encontramos a Philip-Lorca DiCorcia, quien elabora unas imágenes que son (re)constructos basados en instantáneas fotográficas genéricas, escenas cinematográficas y retratos, con una confusión enriquecedora. Otro de los artistas es Gregory Crewdson, quien en ocasiones, a través de sus elaboradas puestas en escena fotográficas, echa mano de escenas paradigmáticas que reelabora en contextos urbanos contemporáneos. En su obra "Untitled", de la serie "Dream House" (2002) vemos cómo una mujer misteriosa flota, inerte, en el extraño estanque en que se ha convertido el salón de su casa, inundado por alguna causa desconocida que roza lo paranormal... No podemos dejar de pensar en la trágica Ofelia de Shakespeare, la Ofelia de los prerrafaelitas, pero en esta ocasión se trata de una Ofelia contemporánea y anónima.

En cuanto a las imágenes de Anna Gaskell, vemos a chicas adolescentes a partir de planos cortos, fragmentados, con una quietud escalofriante. La autora 
plantea historias inquietantes, turbias, empleando como punto de partida imaginerías pertenecientes a cuentos infantiles. Gaskell encuadra estas escenas congeladas en un sentido fílmico, que recuerda tanto al film noir como a las cintas de terror, con alusiones a lo "Inenarrable" a través de la iluminación dramática o a ángulos de la cámara. La plasticidad de las imágenes, combinada con la ambigüedad moral del relato, proporciona un excitante placer visual. Lo narrativo subyace en el corazón de los proyectos de Gaskell; cada una de sus series se centra en una historia vagamente expresada (que se revela a través de de visiones fragmentadas). Las imágenes construidas de esta artista encuentran sus raíces en los primeros tiempos de la fotografía, en las fantásticas imágenes de la niñez victoriana de Julia Margaret Cameron o Lewis Carroll. Asumiendo la naturaleza ficcional del medio, las producciones de Gaskell llevan más allá el debate entre la "verdad" construida de la narrativa en general, y de las imágenes fotográficas en particular.

Las referencias a la pintura son algo recurrente en el remake fotográfico actual, a menudo paradójicamente para reflexionar sobre las propias condiciones de la fotografía. Las fotografías de la serie "Arsenal” (2002) de Theresa Hubbard y Alexander Birchler fueron tomadas en una vieja sala de cine en Berlín, unas semanas antes de que fuera a ser cerrada. Las disposiciones espaciales de estas puestas en escena fotográficas evocan los montajes de las escenas del cine, y la protagonista de la historia remite claramente a la acomodadora que, absorta en sus pensamientos, esperaba fuera del cine en pintura de Edward Hopper "New York Movie” (1939). 


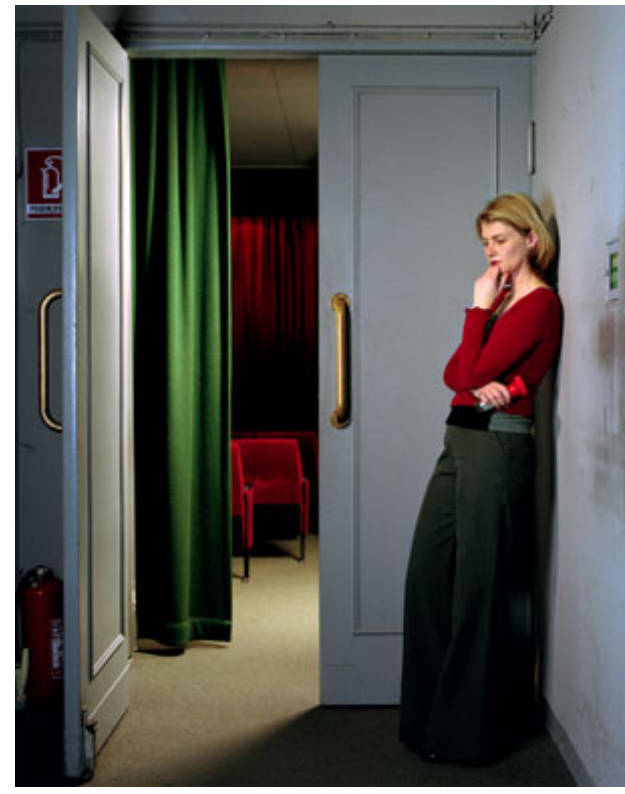

Imagen 10. Theresa Hubbard y Alexander BIrchler: Fotografía de la serie "Arsenal" (2002)

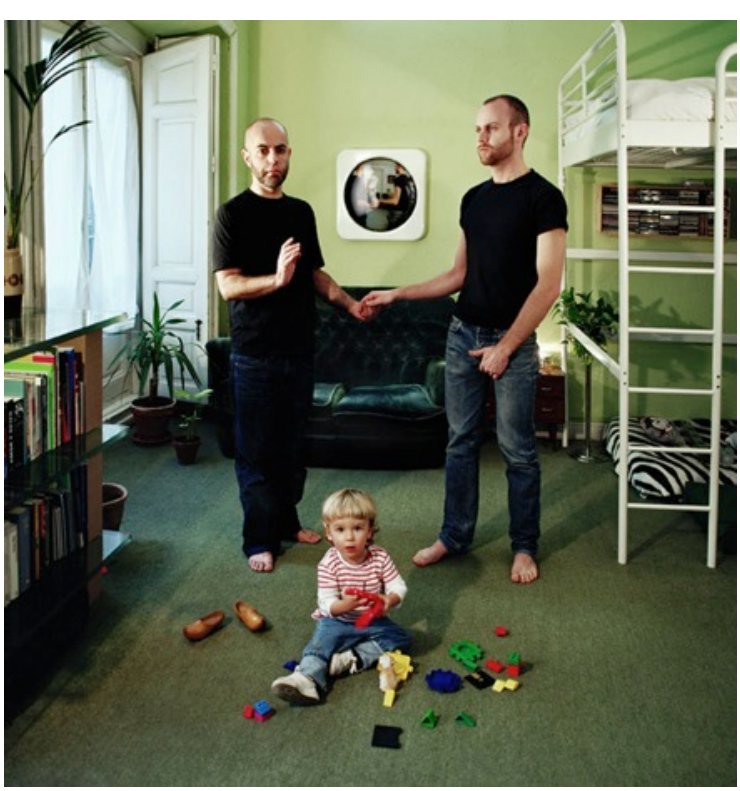

Imagen 11. Félix Fernández y Andrés Senra: "Te quiero no por lo que eres, sino por lo que soy cuando estoy contigo" (2004)

Sin embargo, frente a la solución pictórica de Hopper, el trabajo de Hubbard y Birchler es resultado de una reflexión sistemática acerca del medio fotográfico, que en sí genera esta particular temporalidad, resuelta en forma de secuencia. Hubbard y Birchler se han apropiado, por una parte, de una gramática cinemática y medios de producción propios de las películas. Pero por otra parte, un aspecto cinematográfico importante reside en el efecto del gran formato, que confronta al espectador con figuras a tamaño natural. En último término, la pareja de artistas realiza un trabajo (a través de fotografías, proyecciones, dioramas y escenas) que puede leerse en gran medida como una breve historia del cine y de la imagen cinematográfica fija: una reflexión, metalingüística, acerca de la arquitectura de las apariencias y de la ilusión.

Por otro lado, podemos afirmar que existe un determinante contagio de lo neobarroco $^{9}$ (Calabrese, 1999) en la práctica del remake en fotografía construida actual, expresado fundamentalmente a través de la recurrencia a modos de alegoría: ni lo que la imagen muestra ni lo que el texto enuncia es algo fijado o definitivo, sino que sus significados se verán afectados por transformaciones de su contexto y su recepción, de manera que puede

9 Según desarrolla Omar Calabrese en La era neobarroca (Cátedra, 1999), lo "neobarroco" aparece como una lectura del presente en la que se apela a la historia como ejercicio retórico de intertextualidad extrema. 
potencialmente dirigir a algo otro. Este tipo de fotografías funcionan como una especie de “objetos inespecíficos”, propios del pensamiento alegórico ${ }^{10}$, en tanto que cuentan con una significancia abierta.

En las imágenes fotodramáticas, a pesar de la celebrada transparencia fotográfica, encontramos con frecuencia un fondo ambiguo e informe para el que todavía no tenemos una equivalencia. Y esto se transmite de forma alegórica, indirecta. Mientras que la fotografía ha presumido siempre de mostrarnos la apariencia fiel de las cosas, encontramos que el remake fotográfico permite, a través de imágenes alegóricas, una forma reflexiva de conocimiento. Efectivamente, vivimos en un mundo donde abundan imágenes que son capaces de albergar y de revelar otra significancia en el acto de su consumo. Ante estos objetos, el espectador ha de fijar el significado, detectando ese "algo otro" que podría mutar con el tiempo o las circunstancias. Frente a la antiguamente supuesta y segura cualidad indicial de la fotografía, el remake la hace móvil, voluble, imperfecta, con fisuras y aperturas hacia otros territorios.

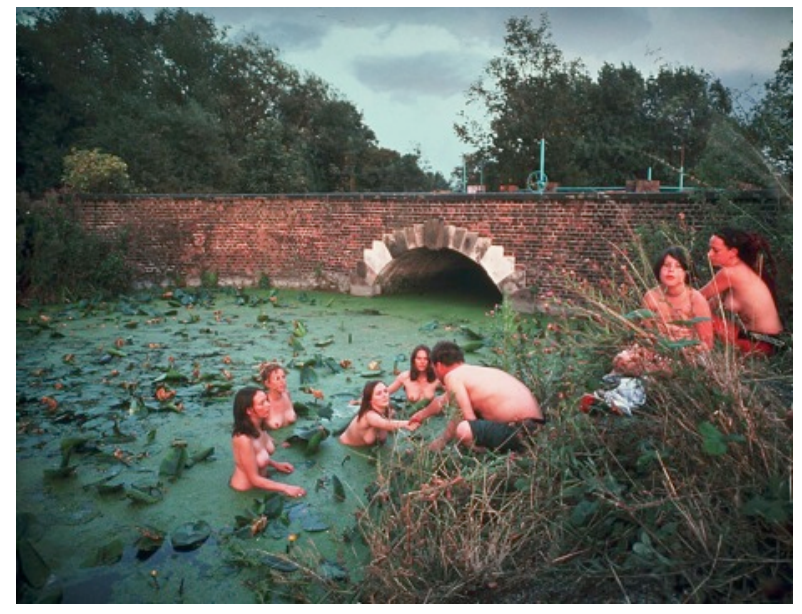

Imagen 12. Tom Hunter: "'Reservoir \#1" (200o), de la serie "Life and Death in Hackney"

Esta idea del remake como alegoría está siendo desarrollada por un número significativo de autores actualmente, como por ejemplo Tom Hunter. Su caso es especialmente interesante como contrapunto a lo que tantas veces se ha criticado en esta tendencia (cuando el remake funciona como un simple ejercicio de estilo). Hunter toma pinturas clásicas como fuente de inspiración para la interpretación fotográfica: Por ejemplo, la camarera del Bar de Folies-Bergère de Manet se convierte en una

\footnotetext{
${ }^{10}$ En Nuevas estrategias alegóricas (Tecnos, 1991), José Luis Brea comenta que en la cultura del hiperconsumo y la sobrebundancia, caracterizada entre otras cosas por la opulencia de las sociedades de la comunicación, la multiplicación de las estrategias de simulación, y el triunfo del artificio, vuelve el barroco y el proceso alegórico de representación. Hoy el panorama de la representación parece, en efecto, haberse alegorizado, afectando esto a todo lo que ocurre en su escena: vivimos en un mundo plagado de una multitud de actos y objetos capaces siempre de otra significancia en el acto de su consumo.
} 
camarera en un pub de Hackney (zona de Londres conocida por sus casasokupas, donde Hunter localiza la mayoría de sus historias), y una "Ofelia" prerrafaelita se convierte en una joven flotando en un río indeterminado en un área suburbana desolada que resulta ser el espacio abierto más cercano que tienen los habitantes de Hackney, con arbustos, hierba y árboles.

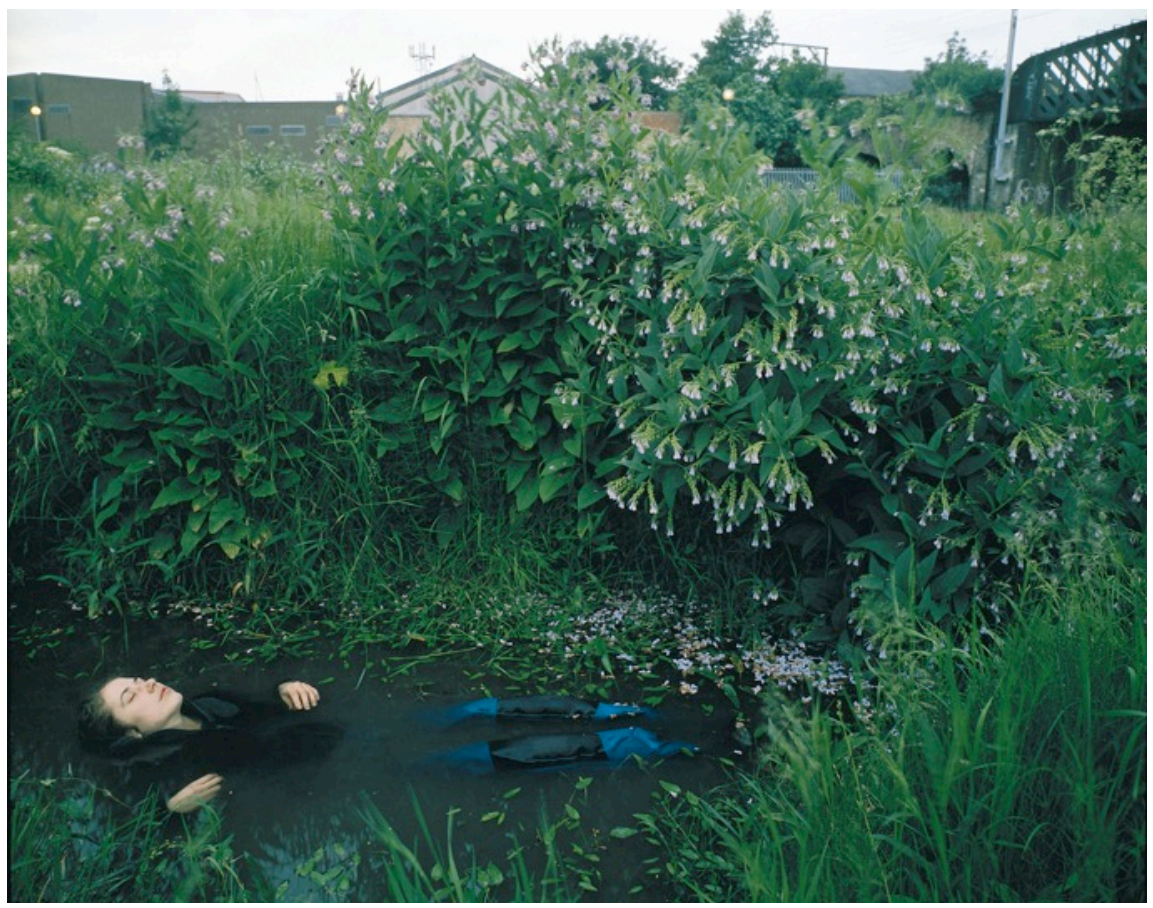

Imagen 13. Tom Hunter: "The Way Home" (200o), de la serie "Life and Death in Hackney"

Su reinterpretación del arquetipo de la “Ofelia” (trabajado también por Gregory Crewdson, como hemos visto, y por otros fotógrafos actuales como Ellen Kooi o Carmela García) tiene un interesante efecto: el sentido de romance y de sentimiento estético de obras anteriores que también beben de la fuente de este personaje todavía permanece en la imagen contemporánea, y esto nos invita a hacernos algunas preguntas interesantes en relación a la propuesta de Hunter: ¿Está esta fotografía tratando el tema que ocupaba a los prerrafaelitas o en esta ocasión se trata de un tema que es relevante hoy? Las mujeres siempre han sido asociadas con la tierra, sus cuerpos con una suerte de fuente de alimento y reproducción. Pensando en las palabras “polvo eres, y en polvo te convertirás”, que nos recuerdan nuestra condición mortal, la Ofelia ahogándose en el estanque es un retorno a la tierra (en este caso, al agua), y el episodio de la obra de Shakespeare es un momento descorazonador, en el completo sentido de la tragedia. 
Sin embargo, Tom Hunter no es mitológico ni filosófico, no intenta explicar ni justificar su trabajo en ningún sentido más allá de sus términos básicos. El autor juega con el conocimiento básico del espectador y las reminiscencias que inevitablemente la imagen de referencia despierta en su fotografía. Esta imagen remite a la "Ofelia" de Shakespeare, quien a su vez bien podría haberla obtenido de alguna otra fuente. La pintura prerrafaelita añade dimensiones a la situación, y finalmente tenemos el entorno suburbano de Hackney, que la contextualiza en un aquí y un ahora, en una problemática específica y contemporánea. La estética de la imagen es impecable; la modelo es apropiadamente frágil y bella, y en vez del etéreo vestido blanco, lleva unos prosaicos pantalones vaqueros. En el paisaje de la escena podemos ver postes de teléfono, y los tejados de las típicas casas suburbanas. En la parte derecha aparece un puente y, aunque no podamos llegar a ver la vía del tren, entendemos que la escena tiene lugar cerca de un puente de ferrocarril. Todos los significantes sugieren un área de desperdicio, la antítesis del romanticismo. FInalmente, el título de la obra ("The Way Home") se refiere a la noticia de la muerte de una joven, publicada en un periódico local de Hackney (entorno y contexto que Hunter emplea como referencia principal en su trabajo).

Charlotte Cotton (2004:55) sugiere que "cuando los motivos visuales históricos son usados en un tema fotográfico contemporáneo (...) actúan como una confirmación de que la vida contemporánea acarrea un grado de simbolismo y preocupación cultural paralelos a otras épocas de la historia, y la posición del arte como cronista de fábulas contemporáneas se reafirma”. En efecto, Hunter parece suscribir esta idea, y encuentra una trascendencia y una iconicidad singular en los acontecimientos más lamentables (y que a veces pasan más desapercibidos) de su contexto. Hunter es un "storyteller" que echa mano de titulares de la "Hackney Gazette" y los articula con imaginería clásica y escenas del East London urbano. Sin embargo, no todo es un trabajo puramente intelectual: es igualmente determinante la finura técnica de sus fotografías, a pesar de su apariencia documental. “The Way Home” es una composición innegablemente bella; cuenta con elementos como el lugar apartado en la naturaleza, el puente, la charca, la figura, y una disposición de flores y pétalos que representan el poder regenerativo y continuo de la vida. La idea romántica 
es conseguida en un sutil pero evidente contexto contemporáneo, también prosaico y feo, al que temporalmente se le adjudica un significado poético. El efecto funciona debido a que, por un lado, las ideas poéticas son claramente evocadas, y por otra, ocurre en un contexto urbano carente de toda poesía, magia y significado. El suburbio contiene lo romántico, y lo romántico contiene el suburbio, en términos de un inter-juego que es más holístico que la estética prerrafaelita debido a que no se trata de un escapismo romántico: opera dentro de un entorno reconociblemente mundano.

En otra de sus fotografías, Hunter retrata a una bailarina erótica desnuda acostada en el suelo de un club de striptease, mostrándola en una pose de desnudo clásico. Además de dignificar la labor del personaje a través de la estilización y comparación con un ideal de belleza clásico, el fotógrafo también tiene otra intención: ella está siendo observada por otros, y Hunter quiere retratar también la manera en que los hombre miran a las mujeres. Este tema lo encontramos desarrollado también en la obra "Picture for Women" de Jeff Wall. Resulta obvio que Tom Hunter tiene una formación obtenida en una escuela de arte, y presumiblemente habrá leído y apreciado el libro Ways of Seeing de John Berger.

También el artista chino Wang Qingsong echa mano de la tradición para realizar planteamientos acerca del tratamiento histórico de la cultura china contemporánea, inclinado a los placeres y trampas de la globalización. Con un tono de fina y discreta ironía, revisa las grandes obras de la Historia del Arte en una especie de homenaje, a modo de relectura de esta historia que entra en contradicción con las interpretaciones occidentales de las mismas. Wang Qingsong emplea técnicas y disposiciones altamente teatrales y deja que la cámara narre historias contemporáneas que son en cierto modo verdaderas e inteligibles. El artista se plantea cuestiones acerca de la posición y el destino de la experiencia de los intelectuales en la historia china. En una era de pérdida de ideales, en la que gente proyecta dudas en relación a los héroes e ideales del pasado, este fotógrafo chino pretende captar escenas que describan esta pérdida de esperanzas que han sido reemplazadas por deseos de dinero y poder.

En 2003 realiza las fotografías "China Mansion" y "Romantique". "China Mansion" encarna la percepción del artista sobre el actual estado de 
globalización: China siempre ha estado dispuesta a invitar a expertos extranjeros en diversos campos (economía, tecnología, arquitectura y cultura) para apoyar y guiar sus procesos de modernización. Sin embargo, el choque cultural también crea contradicciones sociales. Wang Qingsong elabora en esta fotografía una puesta en escena en la que los modelos adoptan el papel de invitados extranjeros, imitando posturas de personajes de obras históricas de Ingres, Manet, Gauguin, Rembrandt, Man Ray... Estos modelos parecen comunicarse y crear ciertas relaciones cordiales a través de sus respectivos momentos cronológicos, así como relaciones con la cultura china. El artista parece desempeñar el papel de un anfitrión un tanto confuso en esta mansión, profusamente decorada con antigüedades orientales y occidentales (el anfitrión es, a la vez, conservador y vanguardista).

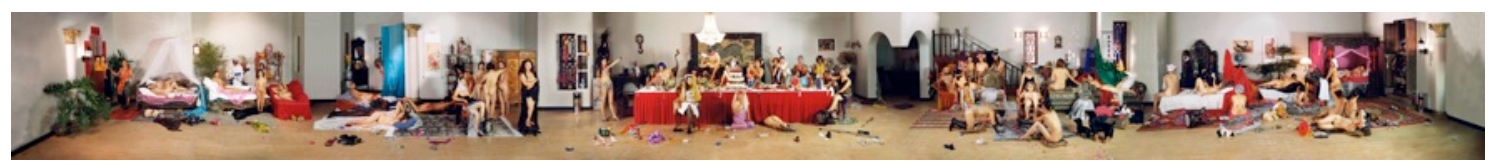

Imagen 14. Wang Qingsong: “China Mansion” (2003)

En “Romantique”, Wang Qingsong nos invita a entrar en un territorio a caballo entre lo que imaginamos que es el cielo de la religión occidental y un jardín pastoral chino. Podemos pensar en un concepto de felicidad artificial (con vegetación de plástico, niebla ligera y blanquecina obtenida a partir de hielo seco, frutas, flores, decoración...), en un paraíso construido. Aquí también se muestran modelos en posturas que reproducen fielmente las posturas de los modelos de Massacio, Velázquez, Botticelli, Rafael y Matisse. Pero además vemos un Buda dorado, bellas princesas, parejas mixtas formadas por un oriental y una occidental, y en suma, gente que parece feliz, pacífica y desprovista de deseo. Con una estética sospechosamente apacible, se subrayan, por contraste, los conflictos potenciales de este complicado diálogo internacional: la comunicación descrita en esta imagen es una comunicación forzada y caótica inscrita en una utopía fabricada por la mano del hombre.

El argentino Marcos López es otro ejemplo de remake configurado a base de pastiches y de samplers, de recombinación de elementos de la historia de la pintura clásica en un contexto local y popular. La estética de sus fotografías a color pintadas a mano es, según ha comentado él mismo en alguna ocasión, 
"barroca, rococó, una postal de Argentina". La intención de López es la de subrayar, repetir, exagerar, mostrar el modo en el que se configura una realidad ecléctica, elaborando retratos que reflejan una identidad nacional desde el punto de vista de sus propias experiencias emocionales. El autor reorienta la realidad mediante su escenificación, su teatralización, tendiendo a lo extremo, a lo esperpéntico. Trabaja con un humor corrosivo, planteando una reflexión sociopolítica del período de los años 90 en Argentina, algo que acaso no pudiera haber sido posible sin una dosis de humor ácido. Sin embargo, en el fondo de su trabajo hay una constante emocional que tiene que ver con algo trágico, que liga compositiva y conceptualmente a elementos de la historia de la pintura occidental.

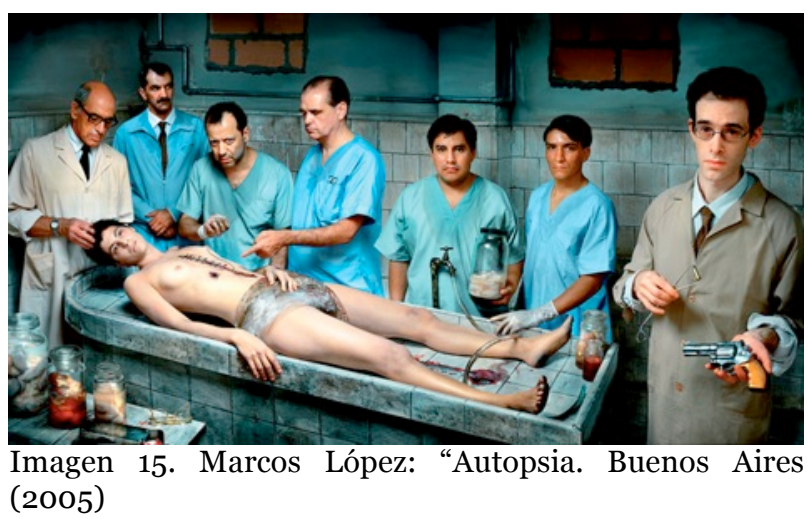

En la fotografía titulada "Autopsia. Buenos Aires" (2005), Marcos López apunta, otra vez, al contexto argentino, planteando cuestiones relacionadas con la sanidad, con la violencia y con la muerte. Y lo hace bajo una forma conocida, rescatando la composición de la pintura clásica "La lección de Anatomía del Dr. Nicolaes Tulp" (1632) de Rembrandt. Pero además opera ofreciendo una relectura de la toma (en este caso, fotografía documental) que el fotógrafo boliviano Freddy Alborta dispara en 1967 ante el cuerpo asesinado del Che Guevara. Podemos decir que se trata de un "remake de un remake". En la versión de López, se recrea una atmósfera de centro de detención clandestino, y la referencia pasa por el tema de los desaparecidos. Y en esta versión, el "Che" es mujer. 


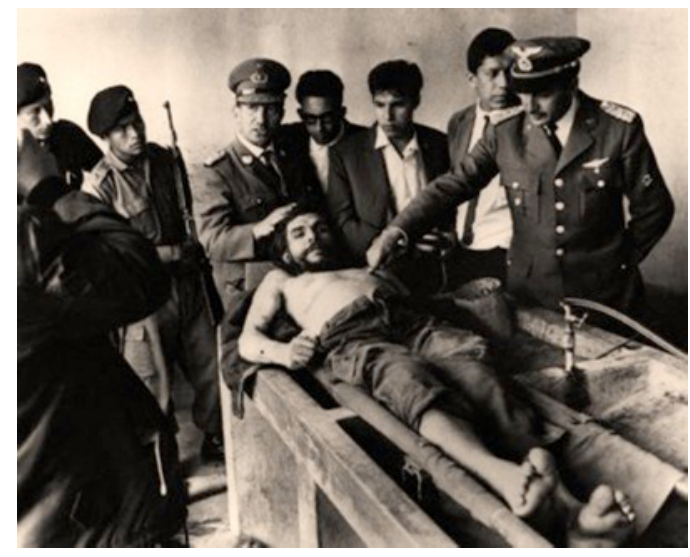

Imagen 17. Freddy Alborta: "La muerte del Che" (1967)

Aparte de las obras de estos artistas que hemos comentado como ejemplos, encontramos numerosos (incontables, podríamos decir) artistas (muchos ya consolidados y con firmes trayectorias, otros muchos emergentes o prácticamente anónimos) que comparten una pasión por la revisión y la transformación de iconos, ideas e imágenes que ya pertenecen un poco a todos, llevándolos a sus respectivos terrenos para ofrecernos un diferencial de experiencia.

No podemos dejar de nombrar los aportes que, ya sea de un modo más sistemático o más puntual, han realizado otros autores. Podemos pensar en las bizarras versiones de clásicos como "Las Meninas", "La Balsa de la Medusa" o "El Nacimiento de Venus" hechas por Joel Peter Witkin, las referencias a los “amantes" de Magritte y a la "Venus del Espejo" de Velázquez de Eileen Cowin y de Karen Knorr, las “Olympias” y “odaliscas” de ésta última en su serie "Life Class", los remakes de pinturas del Barroco español de Erwin Olaf, las numerosas referencias a pinturas clásicas en las impecables fotografías de moda de David LaChapelle y Eugenio Recuenco, e incluso las revisiones de obras contemporáneas (incluso fotográficas) como vemos, por ejemplo, en la versión que Mitra Tabrizian hace de la obra "Insomnia" (1994) de Jeff Wall: en la fotografía de Tabrizian (de 2007), la sórdida y deprimente cocina donde el protagonista de la imagen de Wall aparecía tumbado bajo una mesa se convierte en otra cocina ahora impoluta, blanca, luminosa e impecable, sin que esa sensación de abandono desaparezca en el prometido hogar perfecto hipermoderno. 

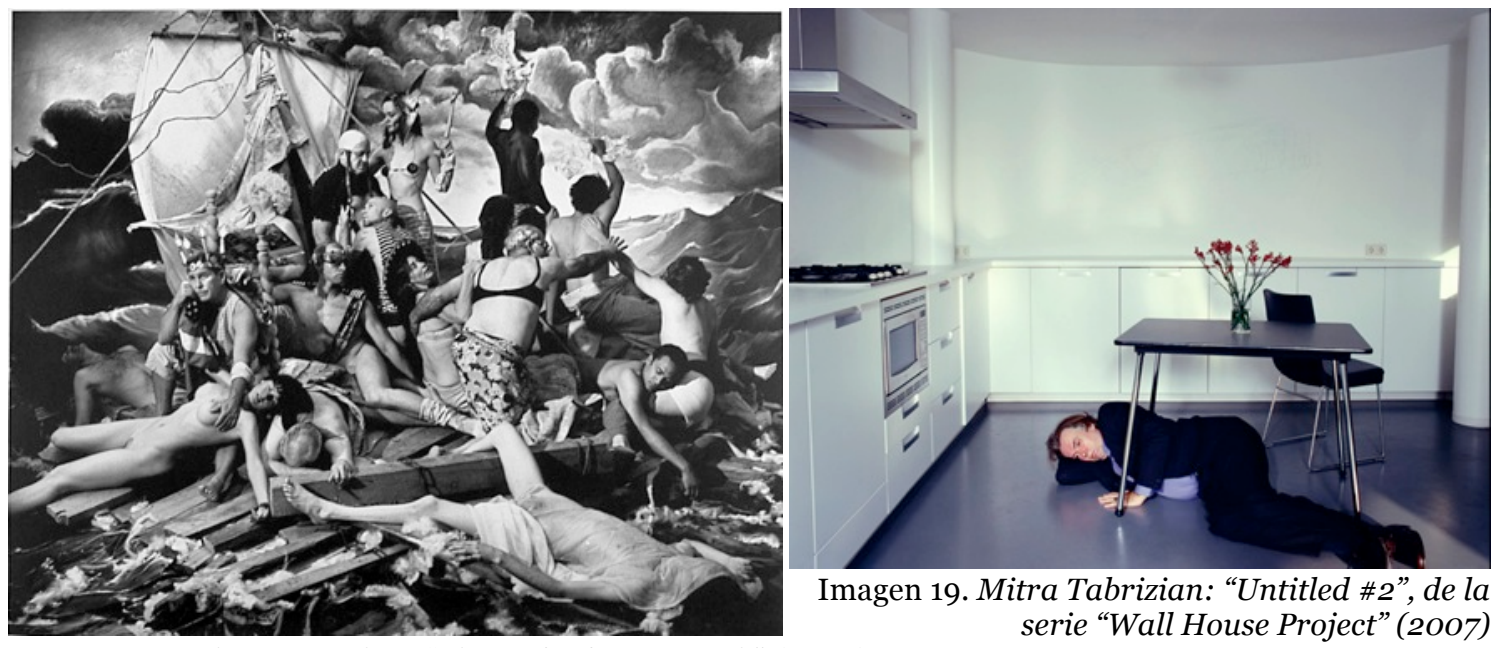

Imagen 18. Joel Peter Witkin: “The Raft of G. W. Bush” (2006)

En ejemplos como los anteriores comprobamos cómo en la fotografía escenificada actual nos encontramos frecuentemente ante situaciones ordinarias, prosaicas y cotidianas en las que de repente se infiltra algo que de un modo más o menos consciente reconocemos, y que añade una dimensión de interés o de grandeza a la escena. Otras veces, los remakes de historias que plantean muchos de estos fotógrafos ocurren en un mundo fantástico o delirante, donde no tenemos por qué existir. En parte, es un arte sobre el arte también: no hay más universo que esta base de datos sobre la que combinar. La definición de posmodernidad de Lyotard (1987) se está revisando ${ }^{11}$ : en realidad, la posmodernidad (y su evolución en la hipermodernidad) puede ser también el proceso que instala nuestra cultura en una gran base de datos que permite una recombinación infinita, y que acaso sea el gran relato.

\section{A modo de conclusión}

Esta investigación ha evidenciado la existencia de una tendencia actual de producción de imágenes fotográficas que toman como punto de partida iconos y obras pertenecientes a un imaginario cultural colectivo, especialmente a la Historia de la Pintura. Se ha desarrollado un panorama que muestra un conjunto de características comunes, obtenido a partir del estudio de un

11 En La condición postmoderna: Informe sobre el saber Jean-François Lyotard elabora todo un análisis que sistematiza elementos de crítica a la modernidad, y describe cómo el relato narrativo donde se expresan las subjetividades es cada vez más libre y múltiple, en oposición a las rígidas e inapropiadas imágenes racionalistas modernas. 
conjunto significativo de artistas y obras que abordan la estrategia del remake a través del medio fotográfico.

Las fotografías pueden ser entendidas como procesos de significación y codificación cultural, cobrando sentido a través del lugar que ocupan en contextos más amplios de significación. La estrategia del remake enfatiza esta idea, infiltrándose en un buen número de propuestas en la fotografía escenificada actual. A través de estas propuestas fotodramáticas se hace posible plantear miradas diferentes sobre obras de arte clásicas (o no tan clásicas), que pueden ser empleadas como puentes para llegar a otros lugares conceptuales. El remake fotográfico puede funcionar como un modo sofisticado de explorar un conocimiento y una iconografía básica que habla de nosotros mismos y de nuestra cultura, proponiendo una reflexión irónica sobre las relaciones que tenemos con nuestras imágenes y nuestra memoria histórica, e incluso artística. En los remakes fotográficos actuales encontramos un gusto y una pasión por la revisión (a veces crítica, a veces lúdica) de iconos, símbolos e ideas que se diluyen en nuestro imaginario colectivo (entendido como una gran base de datos con la que trabajar), a los que se les dan nuevos usos, nuevos alcances que trascienden y superan el referente.

Los remakes fotográficos pueden funcionar como un espejo cultural, psicológico y social (jugando de un modo irónico con el potencial de la fotografía como “espejo de lo real”). Por un lado, funcionan reflejando las nuevas condiciones y preocupaciones contemporáneas. Y por otro, funcionan como objetos culturales de uso y consumo, satisfaciendo nuestra ansia de historias que hablen de nosotros y de nuestra circunstancia. El remake revisa nuestra iconografía y nuestra cultura utilizando sus mismas formas, pero a la vez abriendo nuevos frentes, creando nuevos imaginarios de reflexión y análisis, rompiendo los grandes relatos a favor de "microrrelatos"... Al final, el remake fotográfico no anula el referente, sino que es capaz de intensificar y complicar sus virtudes, funcionando como un verdadero espacio de conflictos culturales.

El remake puede ser una de las formas más íntimas de relacionarse con la obra de arte. La producción y el análisis de remakes fotográficos nos permite descubrir significados ocultos, y desarrollar indagaciones sobre nuestra propia relación con las formas de representación de la realidad, y al final, con la propia 
realidad. Estas imágenes también pueden favorecer reflexiones sobre cómo se producen los imaginarios en los que vivimos y de los que vivimos. En los mejores casos, los remakes pueden provocar una consciencia ante las convenciones de objetividad y fiabilidad de las imágenes, y demostrar cómo la fotografía construida a partir de un icono puede no sólo remitir a un pasado, sino también producir y autorizar nuevas identidades, experiencias, relatos y realidades.

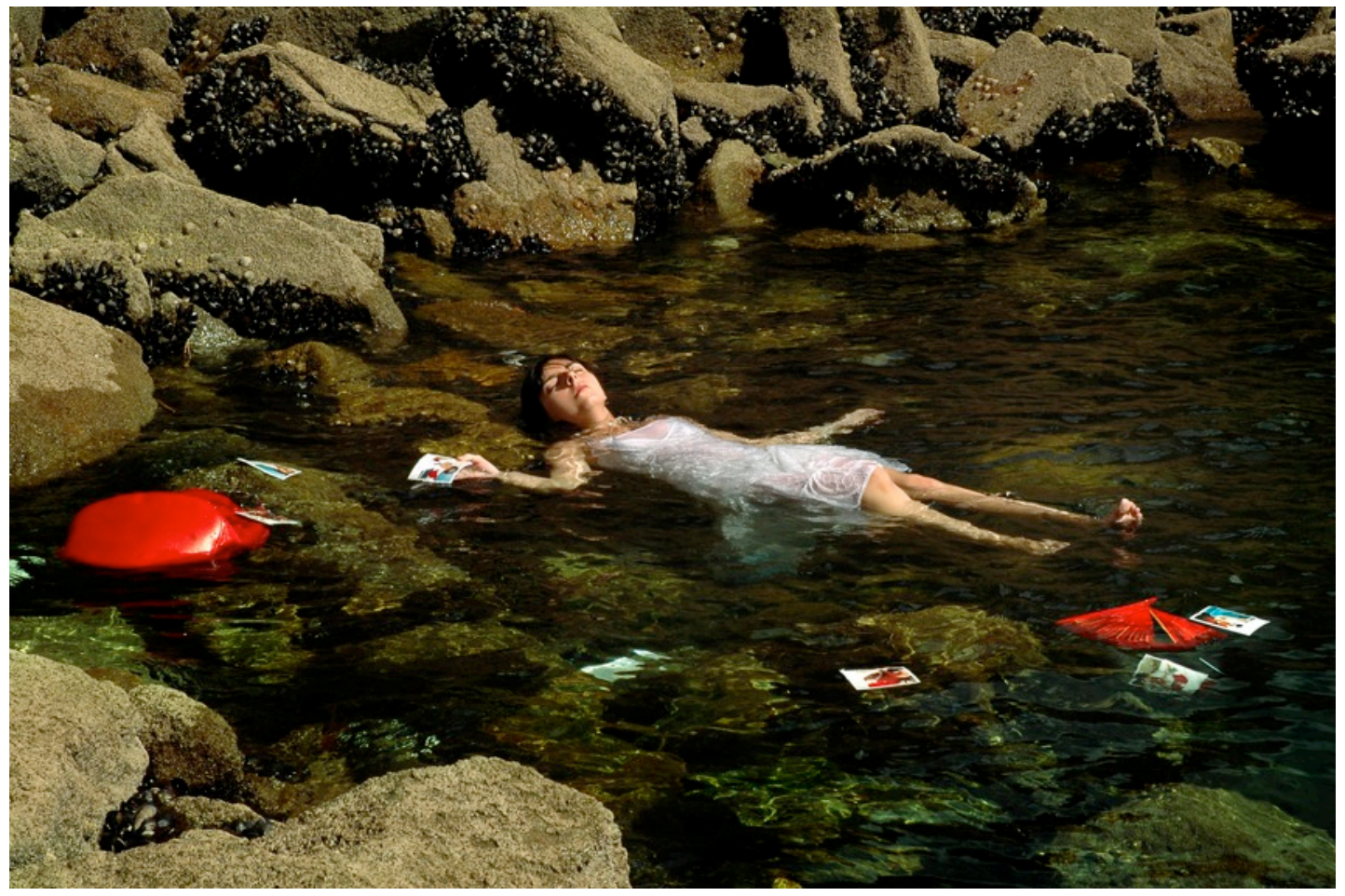

Imagen 20. Maribel Castro: “Ofelia” (2008)

\section{Referencias bibliográficas}

BAQUÉ, Dominique (2003). La fotografía plástica. Un arte paradójico. Barcelona: Gustavo Gili, col. FotoGGrafía.

BARTHES, Roland (1987). "La muerte del autor", en El susurro del lenguaje (pp. 65-71). Barcelona: Paidós.

BARTHES, Roland (1982). "Retórica de la imagen", en Lo obvio y lo obtuso (pp. 29-47). Barcelona: Paidós.

BAUDRILLARD, Jean (2008). Cultura y simulacro. Barcelona: Kairós.

BENJAMIN, Walter (1973). "La obra de arte en la era de la reproductibilidad técnica”, en Discursos interrumpidos I. Madrid: Taurus.

BERGER, John (2002). Modos de Ver. Barcelona: Gustavo Gili.

BOLTER, Jay David/GRUSIN, Richard (2000). Remediation:

Understanding New Media. Massachussets: MIT Press. 
BORGES, Jorge Luis. "Pierre Menard, autor del Quijote” (1944), en Ficciones (1995), pp. 41-55. Madrid: Alianza.

BREA, José Luis (2007). Cambio de régimen escópico: del inconsciente óptico a la e-image. Estudios Visuales no 4 (pp. 145-163), enero 2007. Texto online http://www.estudiosvisuales.net/revista/pdf/num4/JlBrea-4completo.pdf

BREA, José Luis (1991). Nuevas estrategias alegóricas. Madrid: Tecnos, col. Metrópolis.

BRIGHT, Susan (2005). Fotografía hoy. Madrid: Nerea.

CALABRESE, Omar (1999). La era neobarroca. Madrid: Cátedra, col. Signo e Imagen.

CAMPANY, David (ed.) (2007). ¿Qué ha sido de la fotografía?. Barcelona: Gustavo Gili, col. FotoGGrafía.

CHEVRIER, Jean-François (1997). Indiferencia $y$ singularidad. La fotografía en el pensamiento artístico contemporáneo. Barcelona: ed. Llibres de Recerca, MACBA.

CHEVRIER, Jean-François (1996). "Play, drama, enigma”, en (Catálogo) Jeff Wall. Chicago/París/Londres: Chicago Museum of Contemporary Art/ Galerie Jeu de Paume/ Helsinki Museum of Contemporary Art/ Whitechapel Art Gallery.

COTTON, Charlotte (2004). The Photography as Contemporary Art. Londres: Thames and Hudson, col. World of Art.

De DUVE, Thierry (2004). "Jeff Wall: pintura y fotografía", en PICAUDÉ, Valérie/ARBAÏZAR, Philippe (eds.). La confusión de los géneros en fotografía (pp. 36-57). Barcelona: Gustavo Gili.

DERRIDA, Jacques (1975). La diseminación. Madrid: Fundamentos.

DERRIDA, Jacques (1989). Márgenes de la filosofía. Madrid: Cátedra.

FRIED, Michael: Why Photography Matters as Art as Never Before (2008). New Haven: Yale University Press.

GRUNDBERG, Andy (2003). "The crisis of the real: Photography and postmodernism”, en WELLS, Liz (ed). The Photography Reader (pp. 164-179). Nueva York: Routledge.

HOY, Anne H. (1987). Fabrications: Staged, Altered and Appropiated Photographs. New York: Abbeville Press.

KÖHLER, M. (ed.): Constructed Realities: The Art of Staged Photography (2005). Zurich: Edition Stemmle.

KRAUSS, Rosalind E. El inconsciente óptico (1997). Madrid: Tecnos.

KRAUSS, Rosalind E. Cindy Sherman: 1975-1993 (1993). Nueva York: Rizzoli.

LIPOVETSKY, Gilles/CHARLES, Sebastien (2004). Los tiempos hipermodernos. Barcelona: Anagrama, col. Argumentos.

MARTÍN PRADA, Juan (2001). La apropiación postmoderna. Madrid: Fundamentos.

OWENS, Craig (1980). "The Allegorical Impulse: Toward a Theory of Postmodernism", en Revista October, $\mathrm{n}^{\mathrm{0}} 12$ (pp. 67-86).

PEACH ROBINSON, Henry (1869). "Propósito pictorial en fotografía", en FONTCUBERTA, Joan (ed.) (2003). Estética fotográfica. Una 
selección de textos (pp. 53-63). Barcelona: Ed. Gustavo Gili, col. FotoGGrafía.

PICAZO, Gloria/ RIBALTA, Jorge (ed.) (2003). Indiferencia y singularidad. Barcelona: Gustavo Gili, colección FotoGGrafía.

SCHWARTZ, H. (1998). La cultura de la copia. Parecidos sorprendentes, facsímiles insólitos. Madrid: Cátedra.

V.V.A.A. (2007). Jeff Wall. Nueva York: Museum of Modern Art of New York/San Francisco Museum of Modern Art.

V.V.A.A. (1994). Los géneros de la pintura. Una visión actual. Las Palmas de Gran Canaria: Centro Atlántico de Arte Moderno.

WELLS, Liz (ed.) (2003). The Photography Reader. New York: Routledge. 